Article

\title{
Local Perception of Impact-Attitudes-Actions towards Tourism Development in the Urlaubsregion Murtal in Austria
}

\author{
Mike Peters ${ }^{1}$, Chung-Shing Chan ${ }^{2, *}$ (i) and Anita Legerer ${ }^{3}$ \\ 1 Department of Strategic Management, Marketing and Tourism, Faculty of Business and Management, \\ University of Innsbruck, Karl-Rahner-Platz 3, 6020 Innsbruck, Austria; mike.peters@uibk.ac.at \\ 2 Department of Geography and Resource Management, The Chinese University of Hong Kong, Sha Tin, N.T., \\ Hong Kong, China \\ 3 MCI Tourism, Management Center Innsbruck, 6020 Innsbruck, Austria; legerer.anita@gmail.com \\ * Correspondence: ccs_johnson@cuhk.edu.hk; Tel.: +852-3943-6233
}

Received: 15 March 2018; Accepted: 23 June 2018; Published: 6 July 2018

check for updates

\begin{abstract}
Local residents are always the recipients of economic, environmental and socio-cultural impacts from tourism development. Residents' perceived impacts, attitudes towards tourism and the resultant supportive or opposing actions collectively affect the success of tourism, but are not thoroughly understood especially in small regions with rapid growth. The study investigated how the tourism impacts receive local perception, determine local attitudes and in turn lead to active or passive supportive action. The predisposition of linkage between attitude and behaviour is explored with the underlying aspects of impacts. Through the establishment of hypotheses of the relationship and an empirical survey-based study in Urlaubsregion Murtal (URM) in Austria, findings from local populations suggest that local attitude is significantly influenced by tourism impacts. In particular, socio-cultural impacts influenced attitude to a greater extent than the economic and environmental dimensions. The overall prevalent residents' attitude in the URM is highly positive as the respondents indicated a sense of openness towards tourism development and the vast majority agreed that the advantages outweigh the disadvantages. A significant positive relationship between attitude and support is detected. However, the residents also intended to act more passively than actively to supporting tourism development, but the connection from attitude to specific active or passive actions is not apparent.
\end{abstract}

Keywords: active support; passive support; residents' attitude; supportive actions; tourism impact; Urlaubsregion Murtal

\section{Introduction}

Tourism has been an essential impulse for the economic development of regions from the 1950s onward. The growth of a destination implies radical changes for the locals. Residents are exposed to many positively or negatively perceived effects of tourism development. The inclusion of the residents in the tourism operation, destination development and decision-making process was identified as crucial [1].

Since the 1970s, the interest in the residents and their perception towards tourism has increased considerably and thus academics and professionals have been studying residents' attitudes intensively [2-10]. In this context, an attitude is defined as a tendency to respond in a positive or negative way towards a particular idea, object, person or situation and it induces a person's reaction to such stimuli [11]. 
Although resident attitude is a highly discussed topic and one of the most researched topics within tourism studies, the underlying understanding of residents' attitudes towards tourism is not yet comprehensive [9]. Not only is the difficulty in attitudinal measurement itself, it is also challenging to examine how these positive or negative attitudes impact tourism activities and their success. Residents are considered playing an important role in identifying or measuring impacts caused by tourism industries [12], which in turn have a huge influence on destination promotion [13] and image creation.

According to Carmichael [14] and Sharpley [9], there is still limited understanding of how local residents might react to various tourism impacts. Researchers like Jackson and Inbakaran [15] and Nunkoo and Gursoy [16] bypassed the reaction aspect but to investigate residents' support to tourism and prediction of their actions. Whereas Carmichael [14] analyzed how positive or negative attitudes are reflected in residents' behaviour and their subsequent actions, the majority of the studies on residents' attitude towards tourism had neglected the topic of behaviour [17].

This paper aims to bridge this knowledge gap between residents' attitude and behaviour in an active or a passive way based on several notions by scholars $[10,15,17,18]$ The study investigated how the impacts of tourism activities and development received local perception and determined local attitudes. Furthermore, the predisposition of linkage between attitude and behaviour is explored with the factors affecting residents' attitude towards tourism development identified. Tourism impacts would lead to changes in local attitudes towards tourism development and consequently cause supportive or opposing actions. The practical aim of this study is it to create tourism and regional development implications for managers, tourism policy and local governments in order to support the integration of the locals into the development process and thus to improve their attitude towards tourism.

Through an empirical survey conducted to local residents in Urlaubsregion Murtal (URM) in Austria, the results suggest that the attitude of local populations towards tourism development is influenced by their perceived impacts. Socio-cultural impacts are found to exert a greater influence than the economic and environmental dimensions. The findings also reveal an overall prevalent and positive URM residents' attitude towards tourism development and a significant positive relationship between attitude and support although such connections with active or passive supporting actions are not detected.

\section{Literature Review}

\subsection{Tourism Development and Resultant Impacts}

As tourism grows and the interactions between residents and tourists increase, residents are expected to nurse resentment and have increasingly negative attitudes towards tourism [19]. This statement, however, was retracted because some empirical probing produced contrasting results. Nevertheless, when determining how much tourism may influence destinations and their consequent locals' reaction, scholar had created models to analyze the status of destinations [20], including more emphasis on the variable of time [21-25] and on a holistic view of residents' responses [1].

Where tourism development occurs, its impacts are perceived differently throughout different regions, peoples and individuals themselves [14,25]. In principal, tourism impacts can be positive or negative, and followed three basic categories of benefits and costs, namely economic, socio-cultural and environmental impacts $[26,27]$.

Positive economic impacts are mainly derived from direct revenue, employment to tourism industries, foreign exchange earnings, increased public and private investment and additional personal income [25,28-30]. Negative economic impacts are reflected mainly in inflation, rising costs of living and seasonality [31-33].

Environmental impacts were complex and environment-specific. Whereas tourism revenue may improve the existing attractions or contribute to new investments in destinations $[8,25,29,34]$, 
adverse environmental impacts are mainly witnessed in inflex of tourists such as ecological degradation, pollution and congestion problems $[2,25,26,35,36]$.

Lastly, socio-cultural impacts of tourism are considered more intangible [37], context or location specific yielding varied results among researchers [38]. Positively, tourism development brings about improved or additional community services, enhances local cultural identity and overall well-being of the inhabitants [29,35,39-41]. Negatively, various researchers found increased crime rate, degradation of morality, cultural exploitation, crowding and overuse of resources along with tourism development $[8,20,26,35,37,39,42-44]$.

Unfortunately, negative impacts were sometimes ignored or understated because huge efforts were exerted to attracting tourists and economic benefits. Especially, when it comes to determining factors that should be considered in the tourism planning process, there has been a lack of understanding and communication between tourism researchers and community planners [45,46]. It is essential to include the stakeholders including local people and community to develop tourism in a holistic view and sustainable way [47].

\subsection{Theoretical Basis of Residents' Attitude towards Tourism}

The concept of residents' attitudes has been explored extensively in the literature over the last several decades $[27,48]$. The awareness, image and approval of the residents are repeatedly mentioned to be of great importance throughout the tourism development process [13,39,49-51]. While most researchers engaged in applied methods, there was a relatively smaller pool of studies that grounded the findings in theory $[26,40,52]$.

From a psychological perspective, attitude is "a learned tendency to evaluate objects, people, or issues in a particular way" [11], which can include a person's directional (positive, negative or mixed) evaluation of other persons, problems, things or events. However, attitude can sometimes be vague and mixed [11, 52]. Attitude incorporated three components [11], ranging from a cognitive evaluation for opinion or belief segment, to an emotional or feeling segment, and finally an intention to behave in certain ways. Such conceptualization is important to propose an action-led reaction from an attitudinal change as depicted in Figure 1.

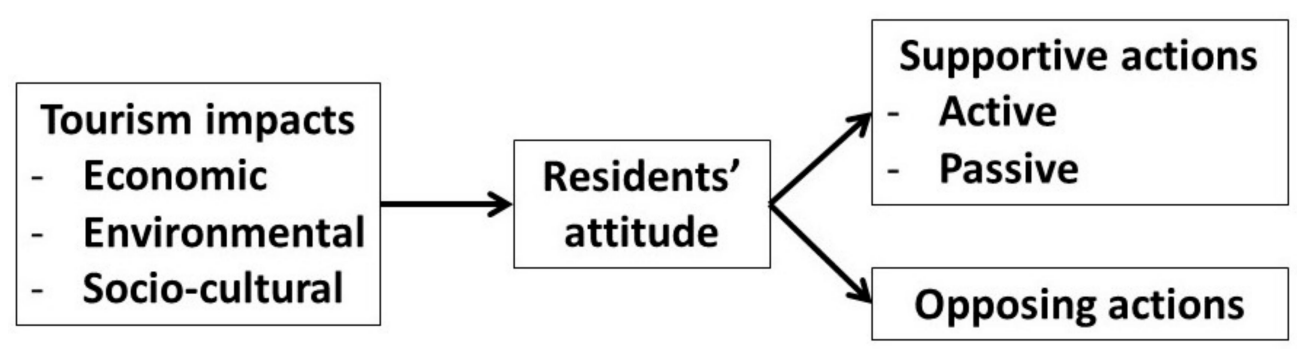

Figure 1. The linkage between tourism impacts, local attitude and actionable behaviour.

To understand residents' attitudes towards tourism development, decision makers such as planners and destination managers need to understand how supportive actions may be driven by local attitude or vice versa. Proper counter-measures to negative attitudes that develop through tourism exchange need to be implemented $[53,54]$. The heterogeneity of local people and their attitudinal dynamism of would determine the success of any destination marketing, management and development plan [50,55].

Most of the tourism impacts studies have been evaluated with the measurement of residents' attitudes towards tourism and how they perceive the impacts within the local community [12]. More researchers in recent years have applied the Social Exchange Theory (SET) to study attitudinal and behavioural aspects of communities [56], especially in areas of tourism stakeholder and decision making $[2,3,6-8,37,57]$. The SET represents a common explanatory basis and comparability based 
on an assumption that "tourism development comes with economic benefits in exchange for social and environmental impacts" [42,58]. The theoretical construct of SET well connects with local perception of tourism impacts because it describes the connection between advantages of all inhabitants and their perception of economic growth [59].

Under the SET predisposition, residents are more generally positive towards tourism if they perceive more benefits and vice versa in an undesirable condition $[2,8,27,37,40,42,60]$ although different observations were revealed in some studies $[23,61]$. These benefits may extend beyond economic revenue but also socio-cultural and environmental factors. More importantly, their positive attitude might even contribute to the support of tourism industry as an exchange when the costs do not exceed the benefits $[2,6,37]$. Such local support might be in form of active or passive way that reacts to tourism development including planning and marketing [61,62].

\subsection{Measurement of Residents' Attitude}

As tourist destinations are quintessentially different, the measurement or the scale of residents' attitude has to be individually and dynamically adjustable for long-term tourism planning [58]. Boley, McGehee, Perdue, and Long [63] highlighted the significance of empowering residents by tailoring tourism marketing and management. Various indices and scales to measure residents' attitude, such as the Residents Empowerment through Tourism Scale, the European Performance Satisfaction Index and the Tourism Impact Attitude Scale have been developed [57,63-66].

These indices and scales have characterized residents' attitude towards tourism development as multi-dimensional framework $[67,68]$. Socio-cultural, economic and environmental factors and four other fields such as crowding and congestion, services and community activities constituted the basis of the scale $[1,58]$.

\subsection{Attitudes Influence Behaviour}

Psychological and behavioural researchers found that the relationship between attitude and behaviour is not always verified but is more likely to be perfectly aligned under particular conditions such as the result of personal experience, the presence of expertise, an expected favorable outcome, a repeated expression of attitude and the stand to win or lose $[69,70]$. This relationship was mainly studied under and evolved from the theory of reasoned action [52,71,72]. This theory was followed by a model stating that beliefs influence attitudes, which then influence behavioural intent and again impacts behaviour $[38,61]$. Subsequent theoretical development has investigated how attitude would influence behaviour differently $[9,14,73]$. These connections were also relevant to areas such as destination marketing and branding [4,74,75]. Furthermore, research on (pro-)environmental behavior often refers to theories of planned behavior or reasoned action but also highlight the gap between articulating intentions and acting environmental friendly [31,76-78].

The evaluation of the connection between tourism impacts, local attitudes and induced behaviour has gone through intensive academic interests but debatable issue [9]. In general, many studies discovered that local respondents who had a positive attitude towards tourism development were supportive of such development and also expressed a clear predominance of benefits rather than costs for the local population [3,5,17-19]. However, it is extremely difficult to come up with one single direction or solution that suits every circumstance [55,79] as local reactions involved complicated issues of education [2], community characteristics [20,80], awareness [81], and understanding and consideration of sustainability [2,38,62,80,82]. In addition, significant relationships between attitude and stage of development, length of stay, gender and distance to the main attractions were found $[6,43,83-85]$.

Although the attitude is expressed rather clearly, the behavioural differentiation between active and passive actions of the residents was rated weakly, and thus it is difficult to imply the direct impacts on tourism development [14]. Attitudes do not always provide the proper basis for the subsequent supportive or opposing actions $[16,31]$ although some researchers noted a prevalent supportive behaviour [80]. 
A list of studies that indicate the theoretical framework, conceptual framework, methods and analyses applied, key findings are provided in Appendix A. These studies of literature showed a great majority of results based on the SET, whereas main research methods included quantitative approaches such as multiple regression and factor analysis [56].

\subsection{Hypothesis Development}

Following the previous literature discussion, the three basic dimensions of impacts caused by tourism development might be beneficial or costly for the local community $[17,20,42,49]$. Based on the most commonly recognized economic contributions of tourism to the local economy $[8,20,29,86,87]$, the first hypothesis $(\mathrm{H})$ is established:

H1. There is a positive association between residents' perceived economic impact of tourism and their overall attitude towards tourism development.

The environmental impacts on residents have become more vital among the three sustainability pillars in balance $[36,88,89]$. The evaluation of environmental impacts $[2,8,17,34,35]$ have addressed in setting up the second hypothesis:

H2. There is a positive association between residents' perceived environmental impact of tourism and their overall attitude towards tourism development.

Lastly, the socio-cultural component of this proposed model $[2,7,8,20,29]$ gives the third hypothesis as:

H3. There is a positive association between residents' perceived socio-cultural impact of tourism and their overall attitude towards tourism development.

As stated earlier, Hockenbury and Hockenbury [11] mentioned that it is commonly assumed that residents' attitudes directly affect their behaviour and actions. This behaviour can be seen more or less strongly, or in other words more active or more passive. Hence, Carmichael's [14] model derived from Abler [71] was used to evaluate the variables of residents' attitude towards tourism development and their support for future development to verify the connections between attitude and behaviour or actions. Before differentiating between the active or passive behaviour, it is necessary to test the presence of general support or opposition towards further tourism development. Based on the explored influence of attitude on behaviour by various researchers [11,14,38,52,73], the fourth hypothesis and its two sub-hypotheses were formulated as follows:

H4. The more positive residents' attitude towards tourism development is, the more likely that residents support further development.

H4.1. The more positive residents' attitude is, the higher the active support for further tourism development.

H4.2. The more negative residents' attitude is, the lower the passive support for further tourism development.

A proposed and testable model constructed upon the hypotheses is as follow:

$$
R A_{\mathrm{i}}=\alpha+\beta_{1}\left(e c o_{i}\right)+\beta_{2}\left(e n v_{i}\right)+\beta_{3}\left(\operatorname{soc}_{i}\right)+\text { control variables } \mathrm{i}+\text { error term }_{\mathrm{i}}
$$

where $R A$ stands for the dependent variable in this model "Residents' Attitude", $\alpha$ represents the constant, $i$ refers to a specific respondent or case, and the parameters $\beta_{1}, \beta_{2}$ and $\beta_{3}$ are the standardized coefficients of the independent variables of the corresponding impact dimensions.

Figure 2 shows the applied model for this study and describes how the hypotheses relate the variables. The levels of economic, environmental and socio-cultural tourism impacts are rated by residents. Their attitude towards tourism development are measured and explained by Hypotheses 1-3. The connection between attitude and consequent action or behaviour is explored, whereby the 
model ends in this stage if there is no significant correlation. If it is positively significant, the type of supportive action, whether active or passive, is examined [14].

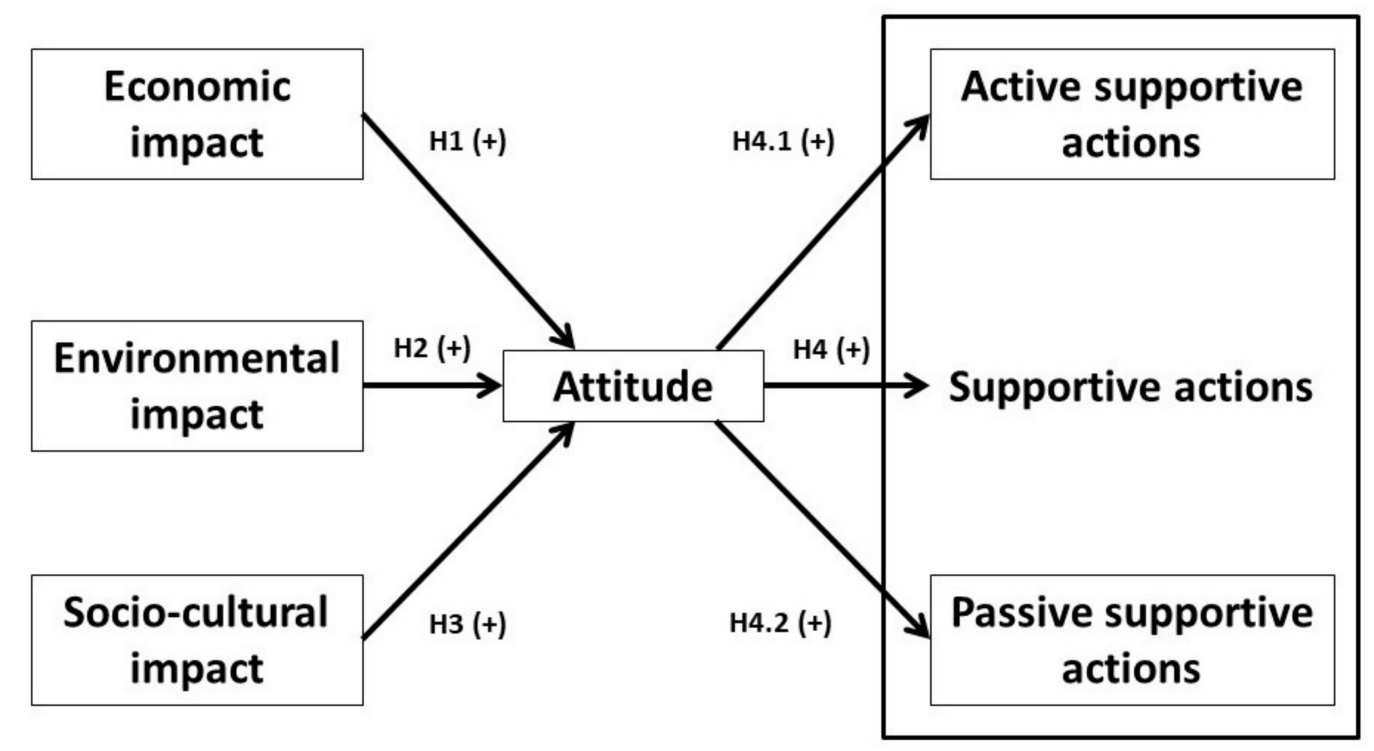

Figure 2. Proposed model and hypotheses of this study.

\section{Study Area and Methodology}

This study explores tourism development of a region in Styria, Austria called 'Urlaubsregion Murtal' (Holiday Region Murtal) (Figures 3 and 4). URM includes two districts: Murtal and Murau; in total there are more than 60 municipalities within the region. In 2012, the two districts Judenburg and Knittelfeld were merged to one district called Murtal (Bezirkshauptmannschaft Murtal), which counted a total of about 104,200 inhabitants in 2017 [90]. About 51\% are women and about $19 \%$ are not older than 19 years, the majority of $62 \%$ is between 20 and 61 years, $19 \%$ are older. The average age is 41 years. The density in the URM is quite low with 33 inhabitants per $\mathrm{km}^{2}$ [90]. Compared to Austria, Styria is strongly characterized by agriculture and farming (of all Austrian agriculture $80 \%$ of farming is located in Styria). However, the URM can be characterized as a region of culinary diversity: a major income is also generated by exporting and selling pumpkin seed oil. Beside their local resources, tradition and culture plays an important role in everyday operations: The growing number of folkloristic offers and associations in the region underlines the trend towards the maintenance of local culture and tradition (e.g., handcraft, local art, local costumes and dances) [90,91]. In the URM, 55\% of the local workforce is employed in the tertiary sector (mainly in trade), $40 \%$ in manufacturing (e.g., electrical and mechanical engineering), and only about $3 \%$ are directly working in tourism businesses such as hotels and restaurants. Thus, the URM is, compared to other Styrian regions not that strongly depending on tourism [92].

This region offers a wide range of natural and man-made attractions in addition to attractive events of various interests. The mountain region attracts tourist in summer with its hiking and biking routes; in winter the URM is known for skiing, cross-country skiing and snowshoe-hiking. Another attraction is the Red Bull Ring in Spielberg where various motor competitions and speed events often accompanied by music festivals take place (e.g., Formula (1), taxi race etc.) [92]. These events can attract up to 95,000 visitors [92]. URM is a fast-growing tourist destination with its tourist arrival increased by $40 \%$ in the past ten years, and recorded 1.26 million overnight stays in 2014 [92]. Tourists on average stay approximately 4 nights and about $60 \%$ of them come from Germany and Hungary. 3000 employees are working in tourism and hospitality. About 1150 businesses offer 18,000 beds in the winter season, more beds are provided in summer (approx. 40,000) by 1220 businesses. However, the occupancy rate is quite low between 20 and $25 \%$ in these two seasons [91]. 


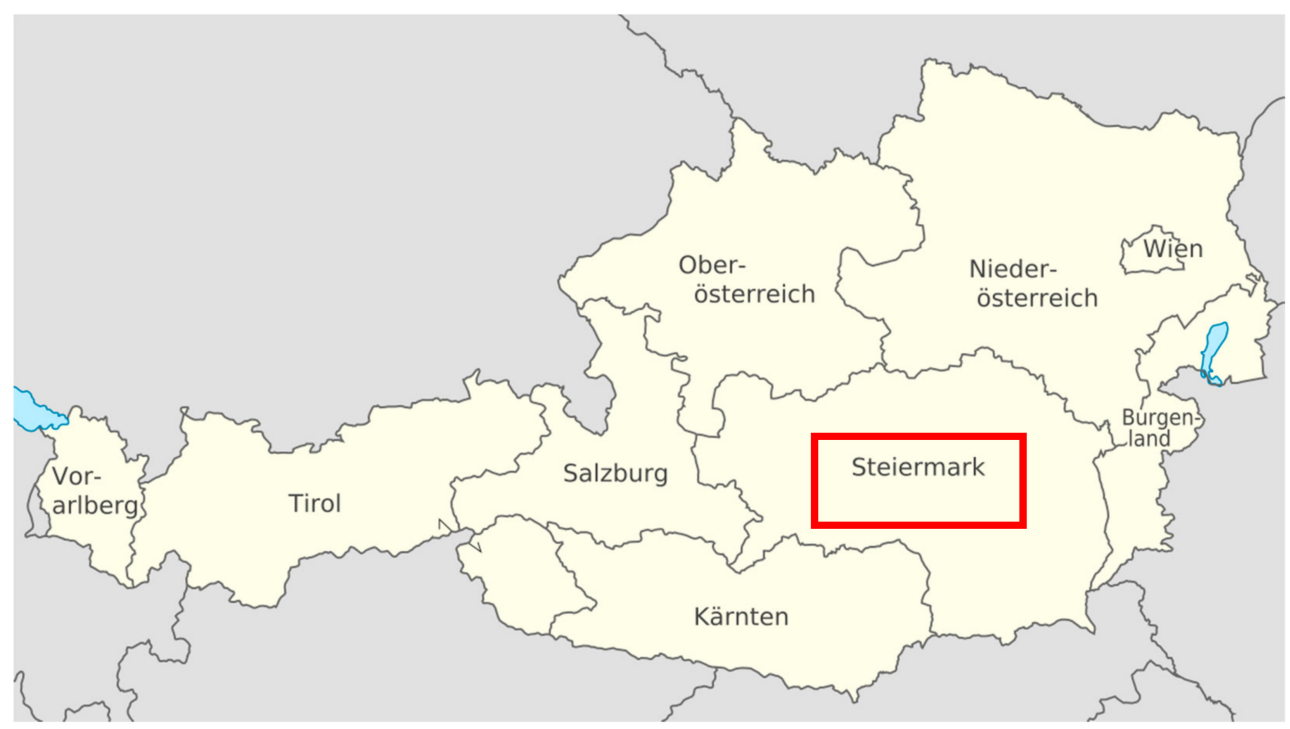

Figure 3. Location of Steiermark state in Austria [47].

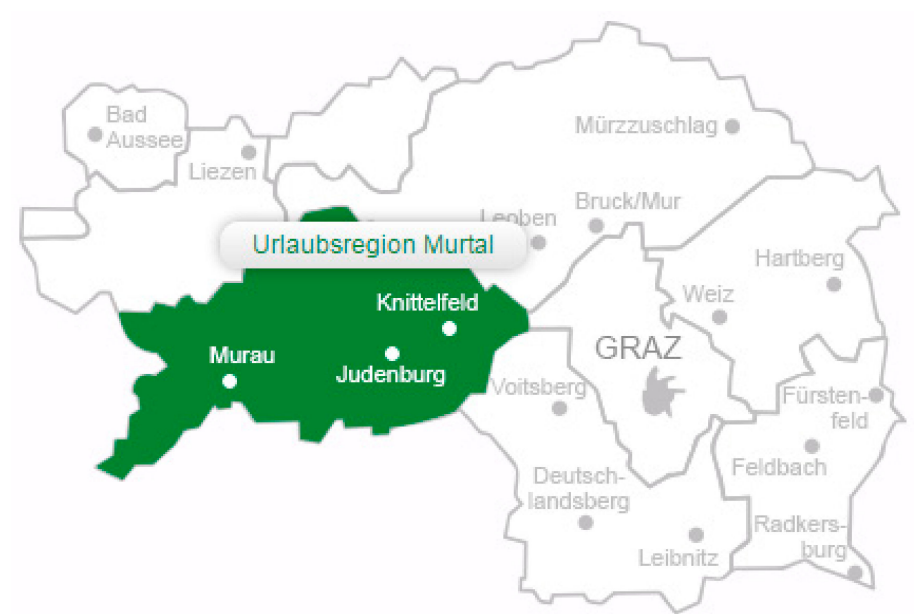

Figure 4. Location of Styria in Steiermark state (Source: [47]).

\subsection{Research Design and Data Collection}

The empirical part is a questionnaire-based survey among inhabitants in the URM. As the research question of this study is to determine residents' attitude towards tourism development and the resulting behavior of the inhabitants, this problem refers to identifying factors that influence the prevalent attitude and its consequences on actions. Therefore, a survey with a quantitative analysis and verification of the hypotheses is deemed appropriate [93-95]. However, in order to assess meaning the residents attach to several constructs used we conducted a round table with eight residents in the regions. They were invited to describe constructs such as economic impact, active or passive support and we presented the items developed from the literature. Some of the items were heavily discussed and re-formulated both with regards to the residents' perception and the operationalization based on earlier research. Finally, the questionnaire was examined and proof-read by several groups of people, including tourism researchers, students from various countries of origin and a small sample of URM residents, before the main survey. This pilot study eliminated any possible mistakes, ambiguities and language problems, and confirmed the clarity and comprehensibility of the questions.

The main survey used a convenience sampling approach that relies upon convenience and access. The questionnaire was created online via http:/ / www.unipark.de, a website provided by the 
Management Center Innsbruck (an institution specialized in tourism study). Invitations to participate were distributed through social media platforms and the email distribution list of the initiative of "Kraft. Das Murtal", and was also sent to all the communities and authorities within the URM.

This channel and the remarks prior to the first part of the questionnaire both ensured that all potential respondents were residents from the URM region. The anonymity of the responses was emphasized before the start so that individual respondents did not have a tendency to hide or bias their responses. Due to the problem of low response rate, a scattered residence distribution across the URM region and the controllability of the respondents by the researchers, a paper-based survey was supplemented by an online version of a self-completion or self-administered questionnaire [96,97]. The printed version was distributed throughout the region by the trained researchers. The surveys were conducted between 5 March and 7 April 2015 with. The use of a combined onsite and online survey is justified to capture the advantages of both methods [94] and applicable in the cases of low response rate [98]. Eventually, 262 participants answered the questionnaire online and 130 answered offline, which eventually contributed to a total of 392 completed responses, a sample size that is larger than the critical degree of sampling error and level of confidence according to Veal [34]. In addition, the researchers in this study discussed the interpretation of two scaling format to avoid misinterpretation of scales [99]. The potential respondents opted for the 6-point scaling with $1=$ fully disagree to 6 = fully disagree.

An operationalization analysis was performed to establish the constructs, the variables and the questions to measure the indicators as shown in Table 1 . Six-point Likert scale (1 denoted fully disagree and 6 denoted fully agree) was used in the questionnaire [100] as earlier research indicated that bipolar 7-point answer scales "took respondents the longest time to complete" ([101], p. 10; [102]). The first three hypotheses examine the variables of economic (items 1-6), environmental (items 7-12) and socio-cultural (items 13-20) impacts associated with the variables of attitude (items 21-22). The correlation between the attitude and support (item 23) aims to explore the fourth hypothesis while the contingency table of hypothesis four concludes the last two sub-hypotheses testing the active or passive support compared to the attitude variable. Item 23 used multiple options ("yes, active support", "yes, passive support" and "no, not supportive").

The questionnaire consists of forty-two questions and was divided into five sections. The first section included twenty statements identifying the level of agreement or disagreement with specific tourism impacts in the three dimensions. The second section consisted of eight statements about the attitude towards tourism development, if and how the participants react or behave accordingly. Next, the third section had six questions about the residents' involvement in and dependency on the tourism industry in attempt to understand the importance of the industry for each person. An open question was added to this part to investigate the respondents' opinion about the region's attractions and the perceived strongest motivators to visit the URM. Finally, the last section included eight questions about the socio-demographic profile of the residents. Details of these questions, their literature foundation and scale of data are provided in Table 1.

As illustrated earlier, the vast majority of researchers have been measuring residents' attitude before and thus indicators derived from the literature were used. The outcome of this study can be used to further explore the circumstance of a fast-growing region such as URM and make comparison between more mature and even saturated destinations. 
Table 1. Operationalization analysis of the questionnaire design.

\begin{tabular}{|c|c|c|c|c|}
\hline Variable & Authors & Indicator & Q & Scale \\
\hline \multirow{6}{*}{$\begin{array}{l}\text { Economic } \\
\text { Impacts }\end{array}$} & \multirow{6}{*}[1,30,86,87,103]{} & Tourism attracts more investments and spending to the region. & 1 & \multirow{6}{*}{ Likert (6) } \\
\hline & & The standard of living has increased because of income through tourism. & 2 & \\
\hline & & Prices of products, services and real estates have increased because of tourism. & 3 & \\
\hline & & Tourism brings economic benefits only to a small group of people. & 4 & \\
\hline & & Tourism creates more jobs for external than for local people in the region. & 5 & \\
\hline & & In general, tourism brings the local economy more positive than negative effects in the region. & 6 & \\
\hline \multirow{6}{*}{$\begin{array}{l}\text { Environmental } \\
\text { Impacts }\end{array}$} & \multirow{6}{*}[2,34,35,104]{} & Tourism provides an incentive for the conservation of natural resources. & 7 & \multirow{6}{*}{ Likert (6) } \\
\hline & & Because of tourism, roads and other public facilities are kept at a higher standard. & 8 & \\
\hline & & Tourism results in unpleasantly crowded and inaccessible places during the high season. & 9 & \\
\hline & & Tourism greatly adds to traffic congestion, noise and pollution. & 10 & \\
\hline & & The construction of hotels and other tourist facilities has destroyed the natural environment in the region. & 11 & \\
\hline & & In general, tourism brings the environment more positive than negative effects in the region. & 12 & \\
\hline \multirow{8}{*}{$\begin{array}{l}\text { Socio-cultural } \\
\text { Impacts }\end{array}$} & \multirow{8}{*}[27,29,35,40,44,68]{} & Meeting tourists from all over the world is a valuable experience. & 13 & \multirow{8}{*}{ Likert (6) } \\
\hline & & Tourism has led to an increase in the availability of recreational facilities for the inhabitants. & 14 & \\
\hline & & Tourism influences the regional culture (traditions and customs, etc.). & 15 & \\
\hline & & Tourism supports the preservation of the regional culture (traditions and customs, etc.). & 16 & \\
\hline & & Tourism supports the restoration of historical buildings. & 17 & \\
\hline & & Tourism causes security and crime problems. & 18 & \\
\hline & & In general, tourism brings the local society and culture more positive than negative effects in the region. & 19 & \\
\hline & & I am in contact with tourists often. & 20 & \\
\hline \multirow{2}{*}{ Attitude } & \multirow{2}{*}[2,17,49,58,104,105]{} & $\begin{array}{l}\text { In general, the advantages resulting from tourism development outweigh the disadvantages for the local } \\
\text { residents in the region. }\end{array}$ & 21 & Likert (6) \\
\hline & & Generally, I am open to further tourism development. & 22 & Likert (6) \\
\hline \multirow{6}{*}{ Behaviour } & \multirow{6}{*}[14,15,17]{} & Support for further tourism development & 23 & Nominal \\
\hline & & I try to convince others of my opinion. (passive) & \multirow{4}{*}{$24-27$} & \multirow{4}{*}{ Likert (6) } \\
\hline & & I regularly inform myself about news. (passive) & & \\
\hline & & I would join a committee to support. (active) & & \\
\hline & & I would join a group to demonstrate. (active) & & \\
\hline & & I'm not interested in this topic, somebody else is responsible. & 28 & Likert (6) \\
\hline
\end{tabular}


Table 1. Cont.

\begin{tabular}{|c|c|c|c|c|}
\hline Variable & Authors & Indicator & Q & Scale \\
\hline \multirow{6}{*}{ Dependency } & \multirow{6}{*}[2,19,29,79,82-84,106]{} & Is your job related to tourism? & 29 & \multirow{6}{*}{$\begin{array}{l}\text { Nominal } \\
\text { Nominal }\end{array}$} \\
\hline & & Were you employed in the tourism industry 5 years ago? & 30 & \\
\hline & & Is any of your family members employed in tourism? & 31 & \\
\hline & & Are you active in politics? & 32 & \\
\hline & & How do you think your and the income of your family members has changed because of tourism? & 33 & \\
\hline & & What does motivate guests to visit the region in your opinion? & 34 & \\
\hline \multirow{8}{*}{ Demographics } & \multirow{8}{*}[19,106,107]{} & Age & 35 & Interval \\
\hline & & Gender & 36 & Nominal \\
\hline & & People in House & 37 & Interval \\
\hline & & Children & 38 & Interval \\
\hline & & Location & 39 & Nominal \\
\hline & & Since when do you live here? & 40 & Nominal \\
\hline & & Job & 41 & Nominal \\
\hline & & Level of education & 42 & Nominal \\
\hline
\end{tabular}

Remarks: " $Q$ " denotes the number of question in the questionnaire. 


\subsection{Data Analysis}

An overview of the data was analyzed with descriptive statistics such as frequencies and crosstabs with the aid IBM Statistical Package for Social Sciences 22. To test the hypotheses, the data entered SPSS 22 for bivariate correlation analysis and multivariate analyses including factor analysis and multiple regression. H1 to H3 were examined by multiple linear regression, which is a useful test to verify or model the relationship between multiple variables [97,108]. Factor analysis aimed to investigate the structure of the association between indicators in each construct and to reduce the number of variables. Regression analysis examined these variables and detected their relations $[62,96,97,108]$. H4 and its sub-hypotheses (H4.1 and H4.2) were tested by bivariate correlation and contingency table to get insights into how the support for further tourism development of the URM's residents is constituted.

\section{Results}

Regarding the 392 respondents' socio-demographic profile, the gender distribution is $43 \%$ male to $57 \%$ female. The average age of the respondents is 36 years old. The profile shows a majority of age group between 21 and $35(46 \%)$ though another $45 \%$ come from the age above 36 . The respondents are generally well educated (over one-third graduated from high school or vocational school, one-third did an apprenticeship and about $27 \%$ graduated from university). Tourism is not the main source of income in the URM because only $16 \%$ are employed or self-employed in that industry. Size of households mainly composes of two to four (78\%). Their length of residence is generally long with almost $75 \%$ of the participants having lived in the region for more than twenty years. The characteristics of the respondents are provided in Table 2. The sample shares characteristics of the residents in Styria although the two datasets might not be comparable due to the difference in sampling methods. Some common socio-demographic characteristics are identified, for example, the majority of respondents are between 20 and 60 years, having a non-tourism occupation.

Table 2. Characteristics of respondents $(n=392)$.

\begin{tabular}{llcc}
\hline \multirow{3}{*}{ Gender } & & Frequency & $\%$ \\
& Male & 223 & 57.0 \\
& Female & 169 & 43.0 \\
Total & $18-20$ & 392 & 100.0 \\
\hline \multirow{4}{*}{ Ege } & $21-35$ & 33 & 8.4 \\
& $36-50$ & 172 & 43.9 \\
& 51 or above & 93 & 23.7 \\
& Missing & 73 & 18.6 \\
& Total & 21 & 5.4 \\
& Primary school & 392 & 100.0 \\
\hline \multirow{4}{*}{ Apprenticeship } & 12 & 3.1 \\
& High school or vocational school & 120 & 30.6 \\
& University or above & 135 & 34.5 \\
& Others & 104 & 26.5 \\
& Missing & 15 & 3.8 \\
& Total & 6 & 1.5 \\
& Self-employed (tourism industries) & 392 & 100.0 \\
\hline Self-employed (non-tourism industries) & 19 & 4.8 \\
& Employed (tourism industries) & 27 & 6.9 \\
& Employed (non-tourism industries) & 42 & 10.7 \\
& Homemaker & 197 & 50.3 \\
& Academic training or education & 12 & 3.1 \\
& Retired & 58 & 14.8 \\
& Unemployed & 27 & 6.9 \\
& Missing & 4 & 1.0 \\
& Total & 6 & 1.5 \\
& & 392 & 100.0 \\
\hline
\end{tabular}


Table 2. Cont.

\begin{tabular}{|c|c|c|c|}
\hline & & Frequency & $\%$ \\
\hline \multirow{4}{*}{ Length of residence } & Less than 10 years & 50 & 12.7 \\
\hline & more than 10 years & 338 & 86.2 \\
\hline & Missing & 4 & 1.1 \\
\hline & Total & 392 & 100.0 \\
\hline \multirow{7}{*}{ Size of household } & 1 person & 45 & 11.5 \\
\hline & 2 persons & 117 & 29.8 \\
\hline & 3 persons & 94 & 24.0 \\
\hline & 4 persons & 83 & 21.2 \\
\hline & 5 or more persons & 34 & 8.7 \\
\hline & Missing & 19 & 4.8 \\
\hline & Total & 392 & 100.0 \\
\hline \multirow{3}{*}{ Is your job related to tourism? } & Yes & 131 & 33.4 \\
\hline & No & 261 & 66.6 \\
\hline & Total & 392 & 100.0 \\
\hline \multirow{3}{*}{$\begin{array}{l}\text { Were you employed in the } \\
\text { tourism industry } 5 \text { years ago? }\end{array}$} & Yes & 113 & 28,8 \\
\hline & No & 279 & 71.2 \\
\hline & Total & 392 & 100.0 \\
\hline \multirow{3}{*}{$\begin{array}{l}\text { Is any of your family members } \\
\text { employed in tourism? }\end{array}$} & Yes & 113 & 28,8 \\
\hline & No & 279 & 71.2 \\
\hline & Total & 392 & 100.0 \\
\hline \multirow{3}{*}{ Are you active in politics? } & Yes & 34 & 8.8 \\
\hline & No & 358 & 91.2 \\
\hline & Total & 392 & 100.0 \\
\hline \multirow{4}{*}{$\begin{array}{l}\text { How do you think your and } \\
\text { the income of your family } \\
\text { members has changed because } \\
\text { of tourism? }\end{array}$} & Yes, increased & 66 & 17.0 \\
\hline & Yes, decreased & 11 & 2.8 \\
\hline & No & 312 & 80.2 \\
\hline & Total & 392 & 100.0 \\
\hline
\end{tabular}

\subsection{Ratings on Tourism Impacts and Future Tourism Development}

Table 3 shows the ratings of local residents in URM on the three dimensions of tourism impacts and the perception of future tourism development. According to the scale adopted, the mean scores closer to 1 for a positive impact statement indicate more positive attitude towards tourism; but more negative attitude for a negative impact statement. Overall, the respondents show the most positive attitude towards the local economic benefits $(\mathrm{m}=1.73)$, which is followed by the socio-cultural impacts $(\mathrm{m}=2.10)$ and environmental impacts $(\mathrm{m}=2.66)$.

Economic and socio-cultural dimensions are relatively positive. The two strongest positive impacts perceived by the local people are the opportunity to "meeting tourists from all over the world is a valuable experience" (socio-cultural; $\mathrm{m}=2.07$ ) and the belief that "tourism attracts more investments and spending to the region" (economic; $\mathrm{m}=2.18$ ). Regarding the relatively negative perception of environmental impacts, traffic congestion, noise and pollution $(\mathrm{m}=4.02)$ is the largest local concern. Revenue leakage and uneven distribution $(\mathrm{m}=3.67)$ and inflation $(\mathrm{m}=3.64)$ are another two most negative economic problems considered by the locals. The overall perception of tourism impacts also follows the order of economic $(m=1.73)$, social $(m=2.10)$ and environmental $(m=2.66)$ dimensions respectively. Regarding the attitudinal aspect, the local respondents believe both that the advantages resulting from tourism development outweigh the disadvantages for the local residents in the region $(m=1.97)$, while they are generally open-minded for further tourism development in the region $(\mathrm{m}=1.66)$. Nevertheless, when moving towards action, they tend to be less passive. More respondents incline to passively inform themselves about tourism-related news $(\mathrm{m}=2.53)$ and to convince others of my opinion $(\mathrm{m}=2.90)$, more than to actively join a committee to support $(\mathrm{m}=4.01)$ or to demonstrate in a group $(\mathrm{m}=4.95)$. The behavioural intention of the respondents shows that they do not consider tourism as someone else's responsibility $(\mathrm{m}=4.38)$. 
Table 3. Ratings on key variables of analysis.

\begin{tabular}{|c|c|c|c|}
\hline & Variables and Indicators & Mean Score & $\begin{array}{c}\text { Standard } \\
\text { Deviation (S.D.) }\end{array}$ \\
\hline \multirow{6}{*}{$\begin{array}{l}\text { Economic } \\
\text { impacts }\end{array}$} & Tourism attracts more investments and spending to the region. $(+)$ & 2.18 & 1.09 \\
\hline & The standard of living has increased because of income through tourism. $(+)$ & 2.72 & 1.23 \\
\hline & $\begin{array}{l}\text { Prices of products, services and real estate have increased because of } \\
\text { tourism. (-) }\end{array}$ & 3.64 & 1.34 \\
\hline & Tourism brings economic benefits only to a small group of people. $(+)$ & 3.67 & 1.51 \\
\hline & Tourism creates more jobs for external than for local people in the region. $(-)$ & 3.17 & 1.43 \\
\hline & $\begin{array}{l}\text { In general, tourism brings the local economy more positive than negative } \\
\text { effects in the region. }\end{array}$ & 1.73 & 0.89 \\
\hline \multirow{6}{*}{$\begin{array}{l}\text { Environmental } \\
\text { impacts }\end{array}$} & Tourism provides an incentive for the conservation of natural resources. $(+)$ & 3.29 & 1.39 \\
\hline & $\begin{array}{l}\text { Because of tourism, roads and other public facilities are kept at a higher } \\
\text { standard. }(+)\end{array}$ & 2.47 & 1.37 \\
\hline & $\begin{array}{l}\text { Tourism results in unpleasantly crowded and inaccessible places during the } \\
\text { high season. (-) }\end{array}$ & 3.59 & 1.44 \\
\hline & Tourism greatly adds to traffic congestion, noise and pollution. $(-)$ & 4.02 & 1.38 \\
\hline & $\begin{array}{l}\text { The construction of hotels and other tourist facilities has destroyed the } \\
\text { natural environment in the region. (-) }\end{array}$ & 3.01 & 1.45 \\
\hline & $\begin{array}{l}\text { In general, tourism brings the environment more positive than negative } \\
\text { effects in the region. }\end{array}$ & 2.66 & 1.35 \\
\hline \multirow{8}{*}{ Social impacts } & Meeting tourists from all over the world is a valuable experience. $(+)$ & 2.07 & 1.25 \\
\hline & $\begin{array}{l}\text { Tourism has led to an increase in the availability of recreational facilities for } \\
\text { the inhabitants. }(+)\end{array}$ & 2.29 & 1.25 \\
\hline & Tourism influences the regional culture (traditions and customs, etc.). (-) & 3.33 & 1.53 \\
\hline & $\begin{array}{l}\text { Tourism supports the preservation of the regional culture (traditions and } \\
\text { customs, etc.). }(+)\end{array}$ & 2.84 & 1.41 \\
\hline & Tourism supports the restoration of historical buildings. $(+)$ & 2.37 & 1.24 \\
\hline & Tourism causes security and crime problems. $(-)$ & 2.70 & 1.40 \\
\hline & I am in contact with tourists often. $(+)$ & 3.37 & 1.67 \\
\hline & $\begin{array}{l}\text { In general, tourism brings the local society and culture more positive than } \\
\text { negative effects in the region. }\end{array}$ & 2.10 & 1.11 \\
\hline \multirow[t]{2}{*}{ Attitude } & $\begin{array}{l}\text { In general, the advantages resulting from tourism development outweigh the } \\
\text { disadvantages for the local residents in the region. }\end{array}$ & 1.97 & 1.109 \\
\hline & Generally, I am open to further tourism development. & 1.67 & 0.983 \\
\hline \multirow{5}{*}{ Behaviour } & I try to convince others of my opinion. (passive) & 2.90 & 1.479 \\
\hline & I regularly inform myself about news. (passive) & 2.53 & 1.453 \\
\hline & I would join a committee to support. (active) & 4.01 & 1.662 \\
\hline & I would join a group to demonstrate. (active) & 4.95 & 1.374 \\
\hline & I'm not interested in this topic, somebody else is responsible. & 4.38 & 1.598 \\
\hline
\end{tabular}

Remarks: "+" denotes a positive tourism impact; "-" denotes a negative tourism impact; for all scales: $1=$ fully disagree to 6 = fully agree.

\subsection{Components of Tourism Impacts}

The indicators of economic, environmental and socio-cultural impact variables were factoranalyzed using principal component analysis (PCA) with a Varimax rotation method. The PCA reproduced or replaced the dataset with fewer possible components and then decide the collective terms for the highly-loaded variables within each component [108]. The Kaiser-Meyer-Olkin (KMO), measure of sampling adequacy and the Bartlett's Test of Sphericity were included in the analysis to determine the suitability of the data. Totally, twenty tourism impact items entered the PCA. Cronbach's Alpha was used to test the internal reliability of each component and the result indicates a quite low reliability of all factors together; however, if the lowest factor is erased the coefficient only rises to 0.658 , which is still a questionable reliability value [108]. Although the construct of community culture displays a low Cronbach's Alpha we decided to retain it because for exploratory constructs scholars seem to accept also Alpha values below the threshold of 0.7. Moreover, the Cronbach's Alpha of the entire set of independent and dependent variables of the dataset reaches 0.863 , which exceeds the critical value of 0.7 [109]. The KMO value above 0.8 and a statistically significant Bartlett's Test of Sphericity both indicated the adequacy of the data for a factor analysis. After examining the factor loading matrix, there is no item with cross-loading on two or more components and the loading below 0.50, and thus all items were appropriate and used in the analysis. Eventually, all components with an eigenvalue above 1.0 were included in further elaborations [108]. Finally, five components are identified and their overall variance explained is $59.81 \%$. 
Table 4 shows the derived five components with their loadings. Each component was named according to the nature of the associated impact items in the group. The first component is Community Prosperity, which comprises items from each impact dimension although the socio-cultural items such as meeting tourists, recreational facilities, regional cultural preservation and restoration of historical buildings predominate. The second component named Community Environment is related to negative aspects including overcrowding, congestion, noise and pollution, destruction of natural habitat and price increase, and security and crime problems. The third component is Community Qualities, which focuses on the standard of living, natural resources and the general environmental protection of the area. Next, two items about limited provision of local benefits and jobs opportunities contribute to another component called Community Leakages. Lastly, the Community Culture comprises the influence on regional culture and the frequency of contact with tourists.

Table 4. Principal component analysis PCA results $(n=392)$.

\begin{tabular}{|c|c|c|c|c|c|c|}
\hline Indicator & $\begin{array}{c}\text { Factor } \\
\text { Loading }\end{array}$ & $\begin{array}{l}\text { Mean } \\
\text { Score }\end{array}$ & S.D. & Eigen-Value & $\begin{array}{l}\% \text { of Total } \\
\text { Variance }\end{array}$ & $\begin{array}{l}\text { Cronbach's } \\
\text { Alpha }\end{array}$ \\
\hline \multicolumn{7}{|c|}{ Community Prosperity } \\
\hline Tourism attracts more investments and spending to the region. & 0.564 & 2.18 & 1.09 & \multirow{8}{*}{5.627} & \multirow{8}{*}{28.135} & \multirow{8}{*}{0.825} \\
\hline $\begin{array}{l}\text { In general, tourism brings the local economy more positive than } \\
\text { negative effects in the region. }\end{array}$ & 0.566 & 1.73 & 0.89 & & & \\
\hline $\begin{array}{l}\text { Because of tourism, roads and other public facilities are kept at } \\
\text { a higher standard. }\end{array}$ & 0.674 & 2.47 & 1.37 & & & \\
\hline Meeting tourists from all over the world is a valuable experience. & 0.527 & 2.07 & 1.25 & & & \\
\hline $\begin{array}{l}\text { Tourism has led to an increase in the availability of recreational } \\
\text { facilities for the inhabitants. }\end{array}$ & 0.730 & 2.29 & 1.25 & & & \\
\hline $\begin{array}{l}\text { Tourism supports the preservation of the regional culture (traditions } \\
\text { and customs, etc.). }\end{array}$ & 0.645 & 2.84 & 1.41 & & & \\
\hline Tourism supports the restoration of historical buildings. & 0.758 & 2.37 & 1.24 & & & \\
\hline $\begin{array}{l}\text { In general, tourism brings the local society and culture more positive } \\
\text { than negative effects in the region. }\end{array}$ & 0.567 & 2.10 & 1.11 & & & \\
\hline \multicolumn{7}{|c|}{ Community Environment } \\
\hline $\begin{array}{l}\text { Prices of products, services and real estates have increased because } \\
\text { of tourism. }\end{array}$ & 0.651 & 3.64 & 1.34 & \multirow{5}{*}{2.653} & \multirow{5}{*}{13.263} & \multirow{5}{*}{0.765} \\
\hline $\begin{array}{l}\text { Tourism results in unpleasantly crowded and inaccessible places } \\
\text { during the high season. }\end{array}$ & 0.708 & 3.59 & 1.44 & & & \\
\hline Tourism greatly adds to traffic congestion, noise and pollution. & 0.632 & 4.02 & 1.38 & & & \\
\hline $\begin{array}{l}\text { The construction of hotels and other tourist facilities has destroyed } \\
\text { the natural environment in the region. }\end{array}$ & 0.657 & 3.01 & 1.45 & & & \\
\hline Tourism causes security and crime problems. & 0.696 & 2.70 & 1.40 & & & \\
\hline \multicolumn{7}{|c|}{ Community Qualities } \\
\hline \multirow{3}{*}{$\begin{array}{l}\text { The standard of living has increased because of income through tourism. } \\
\text { Tourism provides an incentive for the conservation of natural resources. } \\
\text { In general, tourism brings the environment more positive than } \\
\text { negative effects in the region. }\end{array}$} & 0.530 & 2.72 & 1.23 & \multirow{3}{*}{1.497} & \multirow{3}{*}{7.483} & \multirow{3}{*}{0.517} \\
\hline & 0.714 & 3.29 & 1.39 & & & \\
\hline & 0.792 & 2.66 & 1.35 & & & \\
\hline \multicolumn{7}{|c|}{$\begin{array}{ll} & \text { Community Leakages } \\
\end{array}$} \\
\hline \multirow{2}{*}{$\begin{array}{l}\text { Tourism brings economic benefits only to a small group of people. } \\
\text { Tourism creates more jobs for external than for local people in } \\
\text { the region. }\end{array}$} & 0.819 & 3.67 & 1.51 & \multirow{2}{*}{1.132} & \multirow{2}{*}{5.661} & \multirow{2}{*}{0.626} \\
\hline & 0.670 & 3.17 & 1.43 & & & \\
\hline \multicolumn{7}{|c|}{ Community Culture } \\
\hline Tourism influences the regional culture (traditions and customs, etc.). & 0.711 & 3.33 & 1.53 & \multirow{2}{*}{1.053} & \multirow{2}{*}{5.263} & \multirow{2}{*}{0.487} \\
\hline I am in contact with tourists often. & 0.762 & 3.37 & 1.67 & & & \\
\hline
\end{tabular}

$\mathrm{KMO}=0.865 ;$ Bartlett's test of Sphericity $=0.000$; Overall variance explained $=59.81 \%$. For all scales: $1=$ fully disagree to $6=$ fully agree.

\subsection{Hypotheses Validation}

After retaining all impact indicators by the PCA, these items entered a regression analysis together with the other dependent variables including the local attitude (an average of "advantages outweigh disadvantages" and "open towards tourism development") to test H1-H3, i.e., to investigate how the economic, environmental and socio-cultural impacts influence residents' attitude. Following the suggestions of Hornburg and Giering [110], the independent variables refer to the group means of all items in each factor or impact dimension Regression also confirms the coherence of variables and increases the validity of the results. 
A series of hierarchical regression analyses was conducted to test for the hypotheses H1-H3. Several control variables were tested as they might influence the perception of how tourism development impacts on economic, social and environmental conditions. Therefore, the controls (i.e., age, gender, length of residence, job's tourism relatedness, family involvement in tourism industry, involvement in local politics, and employment in the tourism industry) were entered into the first block (Model 1) and the predictors were entered into the second block (Model 2). The findings of the regression analyses are reported in Table 5. The model strength is indicated by the coefficient of determination $R^{2}$ and it indicates the variation in the variable of residents' attitude that can be explained in changes in the independent variables, represented by the means of economic, environmental and socio-cultural items tested in the questionnaire. The adjusted $R^{2}$ is 0.43 , which corresponds to an explained variance of the dependent variable residents' attitude of $43 \%$. The model also passed the $F$-test $(F=25.67)$ of the ANOVA table as the value showed a significant correlation $(p=0.000)$ of the tourism impacts and residents' attitude, while the correlation between the variables in this model is significant. This indicates a non-random relation between the impacts and residents' attitude, which confirms that at least one of the three impacts influence it significantly. Multicollinearity of the model is discounted for the analysis because all the variance inflation factors are below three, the critical value [111].

Table 5. Model of impact-attitude of URM's residents and verification of H1-H3 ( $n=392)$.

\begin{tabular}{|c|c|c|}
\hline & & Dependent Variable: Attitude \\
\hline \multicolumn{2}{|l|}{ Model } & $\beta$ \\
\hline \multirow[t]{11}{*}{1} & (Constant) & $1.471^{* *}$ \\
\hline & Controls & \\
\hline & Age & -0.090 \\
\hline & Gender ${ }^{a}$ & $0.123^{* *}$ \\
\hline & Length of residence ${ }^{b}$ & $-0.119 * *$ \\
\hline & Tourism related job ${ }^{c}$ & 0.004 \\
\hline & Family involvement ${ }^{\mathrm{d}}$ & 0.014 \\
\hline & Involvement in politics $\mathrm{e}$ & 0.089 \\
\hline & Employment in tourism ${ }^{\mathrm{f}}$ & 0.088 \\
\hline & $R^{2}$ & 0.056 \\
\hline & $F$ & $2.86^{* *}$ \\
\hline \multirow[t]{16}{*}{2} & (Constant) & $-0.749 * *$ \\
\hline & Controls & \\
\hline & Age & -0.040 \\
\hline & Gender ${ }^{a}$ & $0.132 * *$ \\
\hline & Length of residence ${ }^{b}$ & -0.041 \\
\hline & Tourism related job ${ }^{c}$ & -0.021 \\
\hline & Family involvement ${ }^{\mathrm{d}}$ & -0.003 \\
\hline & Involvement in politics $\mathrm{e}$ & 0.029 \\
\hline & Employment in tourism ${ }^{\mathrm{f}}$ & 0.097 \\
\hline & Independent Variables & \\
\hline & Environmental Impact & $0.303^{* *}$ \\
\hline & Social Impact & $0.417^{* *}$ \\
\hline & Economic Impact & $0.100 *$ \\
\hline & $R^{2}$ & 0.43 \\
\hline & $\Delta R^{2}$ & 0.374 \\
\hline & $F$ & $25.67^{* *}$ \\
\hline
\end{tabular}

** $p<0.01 ; * p<\overline{0.05 \text {. Controls: }{ }^{\mathrm{a}} \text { Gender: } 0=\text { male, } 1=\text { female; }{ }^{\mathrm{b}} \text { Length of residence: } 0}=10$ years or less, $1=$ more than 10 years; $^{\mathrm{C}}$ Is your job related to tourism? $0=$ yes, $1=$ no; ${ }^{\mathrm{d}}$ Is any of your family members employed in tourism? $0=$ yes, $1=$ no; ${ }^{\mathrm{e}}$ Are you active in politics? $0=$ yes, $1=$ no; ${ }^{\mathrm{f}}$ Were you employed in the tourism industry 5 years ago? $0=$ yes, $1=$ no.

Hypotheses 1, 2 and 3 are accepted because there is a significant relationship between the economic, environmental and socio-cultural variables and residents' attitude although the relationships are generally weak (economic dimension with $\beta=0.10$ ) or marginally moderate (environmental with $\beta=0.303$ and socio-cultural dimension with $\beta=0.417$ ) [112]. Residents' attitudes towards tourism development depend upon their perception of economic, environment and socio-cultural variables 
and the majority of control variables (e.g., whether they work in a tourism related job or whether the family is involved in tourism) only have weak effects on this relationship.

Hypothesis 4 is tested with a correlation and the two sub-hypotheses (H4.1 and H4.2) are examined with a contingency table (Table 6). The variables "resident's attitude" (group means) and "support for further development" are compared to confirm if and to what extent local attitude influences support. The Pearson' Correlation analysis shows a significant relationship between the two variables with a coefficient of 0.289 indicates a positive, but weak relationship. As a result, Hypothesis 4 can be supported. Obviously the more positive residents' attitude towards tourism development is, the more they are willing to support further development.

Table 6 also presents the contingency table for the cross-tabulation of the breakdown of "support for further tourism development" options, i.e., active, passive and no support at all. One can see that the majority of the participants have a positive attitude towards tourism development and that there are more passive than active supporters (57\% versus $26 \%$ respectively). In total, only $13.9 \%$ do not support further tourism development, while $58.6 \%$ support it passively and $27.5 \%$ support it actively. Although Pearson's Chi Square reveals a significant difference between attitude and support, H4.1 and H4.2 cannot be confirmed. The Chi-square value and the Cramer's V of the two sub-groups of respondents are 37.842 and 0.313 respectively. There is no difference between active and passive support for residents who rated their attitude negatively. There is, however, a clear tendency towards passive rather than active support. As a result, this postulates that the more positive residents' attitude the higher the active support and the more negative residents' attitude the lower the passive support, cannot be confirmed.

Table 6. Results of correlation analysis, Pearson's Chi Square test and verification of H4, H4.1 and H4.2 $(n=386)$.

\begin{tabular}{|c|c|c|c|c|c|c|}
\hline & \multicolumn{6}{|c|}{ Pearson's Correlation } \\
\hline \multicolumn{3}{|c|}{ Variable } & \multicolumn{2}{|c|}{$\begin{array}{l}\text { Support for Further } \\
\text { Tourism Development }\end{array}$} & \multirow{2}{*}{$\begin{array}{c}\text { Attitude } \\
1\end{array}$} & \multirow{2}{*}{$\begin{array}{c}\begin{array}{c}\text { Hypothesis } \\
\text { (Result) }\end{array} \\
\text { H4 (supported) }\end{array}$} \\
\hline Attitude & \multicolumn{2}{|c|}{$\begin{array}{l}\text { Pearson's Correlation } \\
\text { Sig. (2-tailed) }\end{array}$} & \multicolumn{2}{|c|}{$\begin{array}{c}0.289^{* *} \\
0.000\end{array}$} & & \\
\hline Gender & \multicolumn{2}{|c|}{$\begin{array}{l}\text { Pearson's Correlation } \\
\text { Sig. (2-tailed) }\end{array}$} & \multicolumn{2}{|c|}{$\begin{array}{l}0.059 \\
0.266\end{array}$} & $\begin{array}{l}0.126^{*} \\
0.016\end{array}$ & \\
\hline \multirow[t]{2}{*}{ Age } & \multicolumn{2}{|c|}{$\begin{array}{l}\text { Pearson's Correlation } \\
\text { Sig. (2-tailed) }\end{array}$} & \multicolumn{2}{|c|}{$\begin{array}{l}-0.196^{* *} \\
0.000\end{array}$} & $\begin{array}{l}-0.092 \\
0.080\end{array}$ & \\
\hline & \multicolumn{6}{|c|}{ Pearson's Chi-Squared $\left(\chi^{2}\right)$ Test-Crosstabulation } \\
\hline $\begin{array}{l}\text { Support for } \\
\text { Further Tourism } \\
\text { Development }\end{array}$ & Active & Passive & No Action & Attitude & & $\begin{array}{l}\text { Hypothesis } \\
\text { (Result) }\end{array}$ \\
\hline $\begin{array}{c}\text { Count } \\
(\%)\end{array}$ & $\begin{array}{c}100 \\
(25.9 \%)\end{array}$ & $\begin{array}{c}220 \\
(57.0 \%)\end{array}$ & $\begin{array}{c}60 \\
(10.4 \%)\end{array}$ & Positive & & \\
\hline $\begin{array}{c}\text { Count } \\
(\%)\end{array}$ & $\begin{array}{c}6 \\
(1.6 \%)\end{array}$ & $\begin{array}{c}6 \\
(1.6 \%)\end{array}$ & $\begin{array}{c}14 \\
(3.5 \%)\end{array}$ & Negative & & \\
\hline \multicolumn{3}{|c|}{ Test } & Value & $\begin{array}{c}\text { Sig. } \\
\text { (2-tailed) }\end{array}$ & & \\
\hline \multicolumn{3}{|c|}{ Pearson's Chi Square } & 37.842 & 0.000 & & H4.1 (rejected) \\
\hline \multicolumn{3}{|c|}{ Cramer's V } & 0.313 & 0.000 & & H4.2 (rejected) \\
\hline
\end{tabular}

\section{Discussion}

\subsection{Theoretical Reflection on the Attitudinal Influences of Tourism Impacts}

The SET and the theory of reasoned action both postulate that as long as tourism benefits received by residents outweigh their perceived costs, these local residents would be more likely to endorse 
tourism development $[38,43]$. This study showed a prevalent positive attitude towards tourism development by the URM's residents who perceived the greater advantages of tourism than the disadvantages, as Akis et al. [19] also stated in their case. Various studies found that the residents who drew benefits from tourism activities were more likely to support tourism development and place more emphasis on the positive tourism impacts $[20,68,80]$. The observations of (i) stronger perceived economic advantages; (ii) a prevalent positive attitude towards tourism; and (iii) a significant correlation between local attitude and support actions all demonstrate that this study concurs with the conclusions from those previous studies.

According to Lepp [18], positive attitude led to openness and support for tourism development, which is implied by the theory of reasoned action. Such observation is proven by the acceptance of Hypothesis 4 in this study that verifies the presence of a positive relationship between local attitude and supportive actions.

Followed the argument by some scholars such as Page [113] on Bjorklund and Philbrick's [72] matrix, the majority of host populations would tend to react passively to tourism policies and development in a way of either silently accepting tourism and its impacts for benefits or perceiving no reversal from the trend of tourism development. The findings from this study substantiate such notion again. The majority of the respondents support tourism development passively and $14 \%$ did not express any interest at all. However, these "no-action" respondents may have a chance of acting against tourism as they possessed negative attitude. The odds are that they may influence and convince others of their opinion. Despite this possibility and the largely passive reaction of the URM community, there is a clear trend towards support for, rather than opposition to, future tourism development.

\subsection{Influences of Tourism Impacts on Local Attitude in the Urlaubsregion Murtal}

The actual influence of perceived tourism impacts on local attitude is deemed destination specific. Brida et al. [5] observed a stronger economic, Sánchez-Cañizares et al. [70] a stronger social impact that positively affected residents' attitude than the social and cultural impacts. The regression model established in the case of URM showed that the three sustainability pillars have a significant relationship with residents' attitude towards tourism development. The socio-cultural dimension, however, is the strongest determinant to local attitude.

Specifically, not all economic impacts are considered positive as the results show that the URM's respondents are particularly concerned about the inflationary impact on the prices of products, services and real estate due to tourism development. This finding is consistent with the literature that revealed the increased costs of land [15], goods and services [81,87], and the overall cost of living [114].

\section{Conclusions and Implications}

This study sheds some lights on tourism planners such as the government or destination management organization to gain an overview of the prevalent residents' attitude in the URM. Although the SET is the most and highly regarded theory in impact-attitude-behaviour study, other theories may also be suitable to inspect local reactions. A closer look at other aspects of residents' attitude may yield in-depth investigation, for example, what the actual active and passive actions are. These research topics would be supported by another theoretical foundation such as community attachment theory or Quality of Life frameworks. Qualitative approach may then be applicable to supplement more information and knowledge to the case.

\subsection{Theoretical and Practical Implications}

This study unraveled some tourism development issues related to positive and negative impacts for locals at the same time. For decision makers such as tourism authorities and policy makers, it is essential to further investigate and understand the whole chain of perception to reactions of the local population [114]. These decision makers have to maximize and manage both the local support for tourism infrastructure and products, as well as a welcoming host population [27]. Across multiple stakeholders in tourist destinations, there can be different and often complex 
structures of value chain and brand perceptions [74,75]. In attempt to keep the attitude of residents towards tourism development under control, tourism authorities are advised to closely monitor attitudinal changes constantly [114]. Particularly for regions like the URM, where destination has only experienced a relatively short, recent but rapid development, the knowledge about local residents' socio-demographic profile and attitudinal situation within the region is important for future planning.

According to the SET, the cost-benefit balance and even distribution are required to expect local support. Tourism planners should therefore raise the awareness of the cost-and-benefit exchange to the URM community and local people experience [58]. To further enhance the positive attitude towards tourism development, the benefits carried by tourism should be highlighted and marketed in the region through practical strategies like internal and domestic branding, fair sharing of resources between locals and visitors [114]. The URM's natural resources are valuable assets that need protection and maintenance [39]. In addition, the environmentally friendly solutions that can be implemented within a region should be communicated to the population and realized with their support, approval and acceptance [114]. On the contrary, the negative impacts with local dissatisfaction and community concern must be tackled and ultimately eliminated practically.

Raising the education level and awareness leads to a better understanding of the tourism industry and inhabitants are generally more supportive of tourism [2]. Moreover, higher involvement leads to higher motivation, which is needed for the future growth and prosperity of the region. Many residents have a clear tendency towards a positive or negative attitude, but they do not act consequently. These people, however, should not be ignored because they could act through different means such as political elections or negative words-of-mouth to deliver undesirable and unfavourable messages within the community and to the external world [14]. These inhabitants' attitude should therefore be cared and evaluated more often, regardless of their intention to act. In parallel, it is constructive to allow local residents to co-create experiences for tourists by showing and retaining their affinity with the URM [82].

\subsection{Areas for Further Study}

Several areas deserve further research attention. First, the geographical concentration on the two districts Murau and Murtal is a limitation for this thesis because the results cannot be compared to other destinations within Austria or the state of Styria. However, this represents an opportunity to explore inter-regional in the future. Second, a longitudinal research is a potential area to keep track of the local attitude and behavioural changes. Furthermore, a qualitative study with decision makers such as politicians, opinion leaders and representatives of tourism associations in the URM involved would be useful to examine and compare attitudinal differences between these stakeholders and local residents.

\subsection{Limitations of the Study}

The authors attempted to measure the link between attitude and supportive action and therefore denied earlier theories positing that behavioural intentions, are immediate antecedents to behavior [69]. The main limitation in its empirical section lies on its statistical shortcoming. Due to the use of convenience sampling, an overall generalization is not possible. The data gained from offline and online assessment was not treated differently, which has been clarified earlier as a way to cope with low response rate. Another weakness is the problem of relatively low Cronbach's Alpha for individual components in the PCA although the overall construct still passed the reliability test. This still caused questionable constructs of variables for regression model building. Furthermore, the complexity of the model calls for a holistic analysis using a structural equation modelling in order to identify latent constructs of residents' attitudes.

Author Contributions: M.P. and A.L. conceived and designed the research; A.L. performed data collection and analyzed the data together with the co-authors; C.-S.C. wrote the first draft paper and further developed the manuscript with M.P.

Funding: This research received no external funding.

Conflicts of Interest: The authors declare no conflict of interest. 


\section{Appendix A}

Table A1. Overview of key studies on local attitude towards tourism.

\begin{tabular}{|c|c|c|c|c|c|c|}
\hline Author(s) & $\begin{array}{l}\text { Conceptual } \\
\text { Framework }\end{array}$ & Analysis & Key Results & Location & Sample Size & Methodology \\
\hline [19] & Butler's hypothesis & $\begin{array}{l}\text { Analysis of the } \\
\text { attitudinal questions }\end{array}$ & $\begin{array}{l}\text { Benefits caused by tourism outweigh the costs and residents } \\
\text { believe in the advantages of tourism. }\end{array}$ & Cyprus & 521 & $\begin{array}{l}\text { Quantitative: } \\
\text { survey }\end{array}$ \\
\hline [39] & $\begin{array}{l}\text { Place } \\
\text { attachment model }\end{array}$ & $\begin{array}{l}\text { Exploratory Facto } \\
\text { Analysis (EFA), } \\
\text { Regression }\end{array}$ & $\begin{array}{l}\text { Tourism development introduced by communities or } \\
\text { entrepreneurs need to pay attention to the local community as } \\
\text { they represent an important part of the development process. }\end{array}$ & Slovenia & 330 & $\begin{array}{l}\text { Quantitative: } \\
\text { survey }\end{array}$ \\
\hline [2] & SET & EFA & $\begin{array}{l}\text { Residents who benefit from tourism are more supportive of the } \\
\text { economic development of a region; however, there is no difference } \\
\text { how these people feel about negative impacts compared to people } \\
\text { who benefit less from tourismRaising the education level and } \\
\text { awareness leads to a better understanding of the tourism industry } \\
\text { and inhabitants are more supportive of tourism in general.The } \\
\text { economic impacts that tourism brings along are evaluated as } \\
\text { positive, but the possible negative impacts such as crowding, } \\
\text { congestion, traffic, litter and crime are not ignored either. }\end{array}$ & $\begin{array}{l}\text { Arizona } \\
\text { (state-wide), } \\
\text { USA }\end{array}$ & 695 & $\begin{array}{l}\text { Quantitative: } \\
\text { postal survey }\end{array}$ \\
\hline [3] & SET & EFA & $\begin{array}{l}\text { Tourism and development is seen positive; however, the link } \\
\text { between attitudes and support for development differs from one } \\
\text { community to another. }\end{array}$ & $\begin{array}{l}\text { Arizona, } \\
\text { USA }\end{array}$ & 392 & Longitudinal \\
\hline [62] & SET & Cluster & $\begin{array}{l}\text { Residents who are more dependent on tourism had a more } \\
\text { positive attitude toward tourism. However, the relationship } \\
\text { between attitudes and support differs among the communities. }\end{array}$ & $\begin{array}{l}\text { Crete, } \\
\text { Greece }\end{array}$ & 194 & $\begin{array}{l}\text { Quantitative: } \\
\text { face to face }\end{array}$ \\
\hline [86] & Not available & EFA & $\begin{array}{l}\text { Tourism impacts are seen as positive, while the area is still in an } \\
\text { early stage of tourism development. }\end{array}$ & $\begin{array}{l}\text { Santa Maria, } \\
\text { Colombia }\end{array}$ & 108 & $\begin{array}{l}\text { Quantitative: } \\
\text { interview via } \\
\text { questionnaire }\end{array}$ \\
\hline [115] & SET & Cluster & $\begin{array}{l}\text { Economic impacts are seen as positive, as well as social and } \\
\text { cultural impacts, but at a lower degree. }\end{array}$ & $\begin{array}{l}\text { Folgaria } \\
\text { (ITA) }\end{array}$ & 293 & $\begin{array}{l}\text { Quantitative: } \\
\text { survey }\end{array}$ \\
\hline [26] & SET & EFA, Regression & $\begin{array}{l}\text { How residents feel about economic, environmental and } \\
\text { socio-cultural impacts influences their level of support of local } \\
\text { tourism policies. If residents perceive tourism impacts more } \\
\text { positively, they are more willing to support future tourism } \\
\text { development policies. }\end{array}$ & Italy & 294 & $\begin{array}{l}\text { Quantitative: } \\
\text { survey }\end{array}$ \\
\hline
\end{tabular}


Table A1. Cont.

\begin{tabular}{|c|c|c|c|c|c|c|}
\hline Author(s) & $\begin{array}{l}\text { Conceptual } \\
\text { Framework }\end{array}$ & Analysis & Key Results & Location & Sample Size & Methodology \\
\hline [83] & Not available & Segmen-tation & $\begin{array}{l}\text { Significant results have been derived regarding the personal and } \\
\text { locational features of the residents as well as the tourist contact, } \\
\text { length of residence, age and language. }\end{array}$ & $\begin{array}{l}\text { Isle of Skye, } \\
\text { UK }\end{array}$ & 123 & $\begin{array}{l}\text { Quantitative: } \\
\text { structured } \\
\text { interviews }\end{array}$ \\
\hline [35] & Not available & Not available & $\begin{array}{l}\text { As a socio-cultural impact study this one found that tourism } \\
\text { changed the organization of the community. }\end{array}$ & Dawlish, UK & 12 & $\begin{array}{l}\text { Qualitative: } \\
\text { interviews }\end{array}$ \\
\hline [14] & $\begin{array}{c}\text { Attitude- } \\
\text { behaviour model }\end{array}$ & EFA & $\begin{array}{l}\text { Many residents have highly positive or negative attitudes, but } \\
\text { they do not behave accordingly. However, it cannot be concluded } \\
\text { that those who are not actively support or reject tourism have no } \\
\text { influence on its future development. }\end{array}$ & $\begin{array}{l}\text { Connecticut, } \\
\text { USÁ }\end{array}$ & 203 & $\begin{array}{l}\text { Quantitative: } \\
\text { telephone survey }\end{array}$ \\
\hline [38] & SET, TRA & SEM & $\begin{array}{l}\text { The positive economic impacts influence residents' support for } \\
\text { tourism development the most. }\end{array}$ & $\begin{array}{l}\text { Sunshine } \\
\text { Coast, } \\
\text { Australia }\end{array}$ & 732 & $\begin{array}{l}\text { Quantitative: } \\
\text { SAQ = self- } \\
\text { administered } \\
\text { questionnaire }\end{array}$ \\
\hline [107] & $\begin{array}{l}\text { Social } \\
\text { representations } \\
\text { theory }\end{array}$ & PCA, Cluster & $\begin{array}{l}\text { The sample was segmented into five clusters and the results were } \\
\text { compared to previous studies. }\end{array}$ & $\begin{array}{l}\text { Gold Coast, } \\
\text { Australia }\end{array}$ & 31 & $\begin{array}{l}\text { Quantitative: } \\
\text { Face to face survey }\end{array}$ \\
\hline [27] & SET & SEM & $\begin{array}{l}\text { Depending on the eco-centric values, use of resources, perceived } \\
\text { costs and benefit of the tourism development, the support of } \\
\text { residents varies. }\end{array}$ & $\begin{array}{l}\text { Virginia, } \\
\text { USA }\end{array}$ & 776 & $\begin{array}{l}\text { Quantitative: } \\
\text { postal survey, }\end{array}$ \\
\hline [55] & SET & SEM & $\begin{array}{l}\text { The findings of this study shot ha when a destination develops } \\
\text { quickly will be almost impossible to please everybody. }\end{array}$ & $\begin{array}{l}\text { Sunshine } \\
\text { Coast, } \\
\text { Australia }\end{array}$ & 430 & Quantitative: SAQ \\
\hline [40] & SET & SEM, CFA & $\begin{array}{l}\text { Tourism development's support by residents is influenced directly } \\
\text { and/or indirectly by } 9 \text { factors: the level of community concern, } \\
\text { eco-centric values, and utilization of tourism resource base, } \\
\text { community attachment, the state of the local economy, economic } \\
\text { benefits, social benefits, social costs, and cultural benefits. }\end{array}$ & $\begin{array}{l}\text { Washington, } \\
\text { Idaho, USA }\end{array}$ & 290 & $\begin{array}{l}\text { Quantitative: } \\
\text { survey }\end{array}$ \\
\hline$[80]$ & Not available & Not available & $\begin{array}{l}\text { Residents who are more dependent on tourism had a more } \\
\text { positive attitude toward tourism, but various negative social } \\
\text { impacts occurred (high prices, drug addiction, vandalism, sexual } \\
\text { harassment and crimes).The local inhabitants supported the } \\
\text { current tourism initiative and also had a positive attitude towards } \\
\text { future development.The study concluded that social impacts of } \\
\text { tourism are never universal and differ from one area to another. }\end{array}$ & $\begin{array}{l}\text { Samos, } \\
\text { Greece }\end{array}$ & 85 & $\begin{array}{l}\text { Quantitative: } \\
\text { pre-structured } \\
\text { questionnaire }\end{array}$ \\
\hline
\end{tabular}


Table A1. Cont.

\begin{tabular}{|c|c|c|c|c|c|c|}
\hline Author(s) & $\begin{array}{l}\text { Conceptual } \\
\text { Framework }\end{array}$ & Analysis & Key Results & Location & Sample Size & Methodology \\
\hline [43] & Not available & Not available & $\begin{array}{l}\text { The residents changed their attitude and support over time. In the } \\
\text { beginning expectations were high, but decreased dramatically. }\end{array}$ & Idaho, USA & 349 & $\begin{array}{l}\text { Quantitative: } \\
\text { secondary data and } \\
\text { survey, scaled items; } \\
\text { Longitudinal }\end{array}$ \\
\hline [6] & SET & $\begin{array}{l}\text { Model test by Gursoy } \\
\text { et al. }\end{array}$ & $\begin{array}{l}\text { The investigated variable of distance to the main tourist attraction } \\
\text { showed significant results with respect to benefit and } \\
\text { cost evaluation. }\end{array}$ & $\begin{array}{l}\text { Virginia, } \\
\text { USA }\end{array}$ & 776 & $\begin{array}{l}\text { Quantitative: } \\
\text { postal survey }\end{array}$ \\
\hline [79] & Not available & Variance & $\begin{array}{l}\text { Residents who are more dependent on tourism can undoubtedly } \\
\text { differentiate between its economic benefits and the social costs. } \\
\text { Furthermore, it showed that residents who are aware of certain } \\
\text { negative impacts are not automatically opposed to further } \\
\text { tourism development. }\end{array}$ & Nadi, Fiji & 199 & $\begin{array}{l}\text { Quantitative: } \\
\text { structured interviews }\end{array}$ \\
\hline [49] & Not available & $\begin{array}{l}\text { SEM-Model adapted } \\
\text { from [104] }\end{array}$ & $\begin{array}{l}\text { The overall perception of tourism impacts influences community } \\
\text { satisfaction and can be used in the planning process for further } \\
\text { tourism development. }\end{array}$ & $\begin{array}{l}\text { Cheju Island, } \\
\text { Korea }\end{array}$ & 732 & $\begin{array}{l}\text { Quantitative: } \\
\text { postal survey }\end{array}$ \\
\hline [68] & TIAS & EFA & $\begin{array}{l}\text { The reliability scores were high, but the scale has not yet } \\
\text { been validated. }\end{array}$ & $\begin{array}{l}\text { Oregon, } \\
\text { Washington, } \\
\text { USA }\end{array}$ & 1436 & $\begin{array}{l}\text { Quantitative: } \\
\text { postal questionnaire }\end{array}$ \\
\hline [18] & TRA & Not available & $\begin{array}{l}\text { Residents' attitude towards tourism is positive and through the } \\
\text { TRA indirect indication indicated that positive attitudes would } \\
\text { lead to pro-tourism behaviour. }\end{array}$ & $\begin{array}{l}\text { Bigodi, } \\
\text { Uganda }\end{array}$ & 48 & $\begin{array}{l}\text { Qualitative: } \\
\text { interviews }\end{array}$ \\
\hline [29] & Not available & Variance & $\begin{array}{l}\text { Residents agree that economic and cultural benefits are reasonable, } \\
\text { but the environmental benefits such as the protection of natural } \\
\text { landscape, is rated worse. }\end{array}$ & Hawaii & 636 & $\begin{array}{l}\text { Quantitative: } \\
\text { postal survey }\end{array}$ \\
\hline [23] & $\begin{array}{l}\text { Four-Strategies } \\
\text { Continuum }\end{array}$ & Not available & $\begin{array}{l}\text { The results show that women are more concerned about negative } \\
\text { tourism impacts than men, although women are more aware of the } \\
\text { positive impacts as well. }\end{array}$ & $\begin{array}{l}\text { North } \\
\text { Island, New } \\
\text { Zealand }\end{array}$ & 124 & $\begin{array}{l}\text { Quantitative: } \\
\text { postal survey }\end{array}$ \\
\hline [116] & $\begin{array}{l}\text { Community } \\
\text { attachment }\end{array}$ & EFA & $\begin{array}{l}\text { Length of residency and attachment to the region showed a } \\
\text { significant relationship. }\end{array}$ & $\begin{array}{l}\text { Montana, } \\
\text { USA }\end{array}$ & 1128 & $\begin{array}{l}\text { Quantitative: postal } \\
\text { survey- } \\
\text { scaled items }\end{array}$ \\
\hline [105] & SET & Regression & $\begin{array}{l}\text { Through public relation campaign the residents' attitude can be } \\
\text { influenced in a positive way and even lead to support further } \\
\text { tourism development. }\end{array}$ & $\begin{array}{l}\text { Arizona, } \\
\text { USA }\end{array}$ & 1403 & $\begin{array}{l}\text { Quantitative: SAQ, } \\
\text { scaled items }\end{array}$ \\
\hline
\end{tabular}


Table A1. Cont.

\begin{tabular}{|c|c|c|c|c|c|c|}
\hline Author(s) & $\begin{array}{l}\text { Conceptual } \\
\text { Framework }\end{array}$ & Analysis & Key Results & Location & Sample Size & Methodology \\
\hline [16] & SET, identity theory & EFA, Regression & $\begin{array}{l}\text { Residents' attitudes towards tourism impacts do not always serve } \\
\text { as a basis for assumptions on the subsequent behaviour. }\end{array}$ & Mauritius & 300 & Quantitative: SAQ \\
\hline [13] & Identity theory & SEM, CFA & $\begin{array}{l}\text { Cognitive components had direct effects on the support for } \\
\text { tourism projects and these behaviours should be encouraged even } \\
\text { more by involving the residents into the industry. }\end{array}$ & Wales & 307 & $\begin{array}{l}\text { Quantitative: } \\
\text { online survey }\end{array}$ \\
\hline [81] & SET & Cluster analysis & $\begin{array}{l}\text { The awareness of positive as well as negative effects is existent, } \\
\text { but the residents are rather uncertain if tourism development and } \\
\text { the increasing number of arrivals is in their best interest. }\end{array}$ & $\begin{array}{l}\text { Balearic } \\
\text { Islands }\end{array}$ & 791 & $\begin{array}{l}\text { Quantitative: } \\
\text { postal survey }\end{array}$ \\
\hline [53] & $\begin{array}{l}\text { Convergent } \\
\text { stakeholder theory }\end{array}$ & EFA, Variance & $\begin{array}{l}\text { Significant differences in residents' attitudes towards the kind of } \\
\text { benefits they receive from tourism. }\end{array}$ & $\begin{array}{l}\text { Sunshine } \\
\text { Coast, } \\
\text { Australia }\end{array}$ & 732 & $\begin{array}{l}\text { Quantitative: little } \\
\text { box drop survey }\end{array}$ \\
\hline [114] & Not available & EFA, Cluster & $\begin{array}{l}\text { The "public service and environment focused group" was mostly } \\
\text { concerned with the availability of amenities, facilities, and } \\
\text { environmental issues; the "community focused group" was } \\
\text { generally concerned with the social and cultural impacts; the } \\
\text { "community-public service and environment focused group" } \\
\text { comprised those respondents who considered both sets of issues; } \\
\text { and the "inconsequential group" included those who did not have } \\
\text { any specific opinion. }\end{array}$ & Turkey & 613 & $\begin{array}{l}\text { Quantitative: } \\
\text { structured } \\
\text { survey questionnaire }\end{array}$ \\
\hline [84] & $\begin{array}{l}\text { Tourism } \\
\text { dependence }\end{array}$ & Variance analysis & $\begin{array}{l}\text { One group of studies suggests a direct relationship between the } \\
\text { level of tourism development in a community and the presence of } \\
\text { negative resident attitudes. }\end{array}$ & $\begin{array}{l}\text { Utah, Idaho, } \\
\text { USA }\end{array}$ & 528 & Quantitative: SAQ \\
\hline [51] & SET, TRA & EFA & $\begin{array}{l}\text { More positive attitudes towards economic, socio-cultural and } \\
\text { environmental impacts lead to greater support. This study } \\
\text { revealed that the image of a destination influences the residents' } \\
\text { attitude towards tourism impacts and their level of support. }\end{array}$ & $\begin{array}{l}\text { Kavala, } \\
\text { Greece }\end{array}$ & 481 & $\begin{array}{l}\text { Quantitative: } \\
\text { structured SAQ }\end{array}$ \\
\hline [59] & SET & EFA, Variance & $\begin{array}{l}\text { Not only were residents' expectations of tourism development not } \\
\text { met, but also the people dependent on tourism (e.g., because they } \\
\text { are employed in the tourism sector) did not have a } \\
\text { positive attitude. }\end{array}$ & $\begin{array}{l}\text { Cape Coast, } \\
\text { Elmina, } \\
\text { Ghana }\end{array}$ & 464 & $\begin{array}{l}\text { Quantitative: } \\
\text { structured } \\
\text { interviews }\end{array}$ \\
\hline [20] & Not available & EFA & $\begin{array}{l}\text { Differences between various cases are shown and the residents in } \\
\text { Turkey are less supportive and more negative towards } \\
\text { tourism impacts. }\end{array}$ & $\begin{array}{l}\text { Urgup, } \\
\text { Turkey }\end{array}$ & 241 & $\begin{array}{l}\text { Quantitative: } \\
\text { household survey }\end{array}$ \\
\hline
\end{tabular}


Table A1. Cont.

\begin{tabular}{|c|c|c|c|c|c|c|}
\hline Author(s) & $\begin{array}{l}\text { Conceptual } \\
\text { Framework }\end{array}$ & Analysis & Key Results & Location & Sample Size & Methodology \\
\hline [85] & Butler's TALC & Not available & $\begin{array}{l}\text { In this case, the destination is standing only at the beginning of } \\
\text { tourism development. Residents' attitude toward positive and } \\
\text { negative impacts was thus ambivalent. }\end{array}$ & Riga Latvia & 250 & $\begin{array}{l}\text { Quantitative: } \\
\text { survey- } \\
\text { scaled items }\end{array}$ \\
\hline [117] & SET & Multigroup analysis & $\begin{array}{l}\text { In this study, variations were found, leading to differences in } \\
\text { certain relationships due to the evolutionary path followed } \\
\text { by destinations. }\end{array}$ & $\begin{array}{l}\text { Algarve, } \\
\text { Portugal } \\
\text { and Huelva, } \\
\text { Spain }\end{array}$ & 769 & $\begin{array}{l}\text { Quantitative: } \\
\text { questionnaire survey }\end{array}$ \\
\hline [17] & SET & Variance, SEM & $\begin{array}{l}\text { The results showed that positive impacts outweigh the negative } \\
\text { ones. A positive residents' attitude is of great importance when it } \\
\text { comes to behavioural aspects and a favorable attitude towards } \\
\text { further tourism development. }\end{array}$ & $\begin{array}{l}\text { Huelva, } \\
\text { Spain }\end{array}$ & 400 & $\begin{array}{l}\text { Quantitative: postal } \\
\text { survey- } \\
\text { scaled items }\end{array}$ \\
\hline [82] & SET & EFA, Regression & $\begin{array}{l}\text { If residents benefit from tourism, they have a more positive } \\
\text { attitude toward tourism and its future development. }\end{array}$ & $\begin{array}{l}\text { Washington, } \\
\text { NC, USA }\end{array}$ & 130 & $\begin{array}{l}\text { Quantitative: } \\
\text { postal survey }\end{array}$ \\
\hline [54] & Not available & EFA, Cluster & $\begin{array}{l}\text { This study rated the importance of community-oriented issues } \\
\text { and came to the conclusion that residents who are in favor of } \\
\text { tourism rate the importance higher than others. }\end{array}$ & $\begin{array}{l}\text { New } \\
\text { Zealand }\end{array}$ & 1062 & $\begin{array}{l}\text { Quantitative: } \\
\text { postal survey }\end{array}$ \\
\hline$[50]$ & $\begin{array}{l}\text { community } \\
\text { participation }\end{array}$ & Not available & $\begin{array}{l}\text { There is a strong support of tourism development by inhabitants, } \\
\text { but they are rather not or only a few involved in the planning } \\
\text { processes. To reach sustainability the inclusion of residents should } \\
\text { be considered. }\end{array}$ & Iran & 250 & $\begin{array}{l}\text { Quantitative: } \\
\text { survey- } \\
\text { scaled items }\end{array}$ \\
\hline
\end{tabular}




\section{References}

1. Ap, J.; Crompton, J.L. Developing and testing a tourism impact scale. J. Travel Res. 1998, 37, $120-130$. [CrossRef]

2. Andereck, K.L.; Valentine, K.; Knopf, R.; Vogt, C.A. Residents' perception of community tourism impacts. Ann. Tour. Res. 2005, 32, 1056-1076. [CrossRef]

3. Andereck, K.L.; Vogt, C.A. The relationship between residents' attitudes toward tourism and tourism development options. J. Travel Res. 2000, 39, 27-36. [CrossRef]

4. Braun, E.; Kavaratzis, M.; Zenker, S. My city-my brand: The different roles of residents in place branding. J. Place Manag. Dev. 2013, 6, 18-28. [CrossRef]

5. Brida, J.G.; Osti, L.; Disegna, M. Residents' perceptions of tourism impacts and attitudes towards tourism policies. Tour. Int. Multidiscip. J. Tour. 2014, 9, 2-48.

6. Jurowski, C.; Gursoy, D. Development of regional tourism organizations: Conditions, expectations and contradictions. Ann. Tour. Res. 2004, 31, 296-312. [CrossRef]

7. Lankford, S.V. Attitudes and perceptions toward tourism and rural regional development. J. Travel Res. 1994, 32, 35-43. [CrossRef]

8. Perdue, R.R.; Long, P.T.; Allen, L. Rural resident tourism perceptions and attitudes. Ann. Tour. Res. 1987, 41, 420-429. [CrossRef]

9. Sharpley, R. Host perceptions of tourism: A review of the research. Tour. Manag. 2014, 42, 37-49. [CrossRef]

10. Young, C.A.; Corsun, D.L.; Baloglu, S. A taxonomy of hosts visiting friends and relatives. Ann. Tour. Res. 2007, 34, 497-516. [CrossRef]

11. Hockenbury, D.H.; Hockenbury, S.E. Discovering Psychology, 5th ed.; Worth Publishers: New York, NY, USA, 2011; ISBN 978-1429216500.

12. Monterrubio Cordero, J.C. Residents perception of tourism: A critical theoretical and methodological review. Cienc. Ergo Sum 2008, 15, 35-44.

13. Palmer, A.; Koenig-Lewis, N.; Jones, L.E.M. The effects of residents' social identity and involvement on their advocacy of incoming tourism. Tour. Manag. 2013, 38, 142-151. [CrossRef]

14. Carmichael, B.A. A matrix model for resident attitudes and behaviours in a rapidly chnaging tourist area. Tour. Manag. 2000, 21, 601-611. [CrossRef]

15. Jackson, M.S.; Inbakaran, R.J. Evaluating residents' attitudes and intentions to act towards tourism development in regional Victoria, Australia. Int. J. Tour. Res. 2006, 8, 355-366. [CrossRef]

16. Nunkoo, R.; Gursoy, D. Residents' support for tourism: An identity perspective. Ann. Tour. Res. 2012, 39, 243-268. [CrossRef]

17. Vargas-Sánchez, A.; Porras-Bueno, N.; de los Ángeles Plaza-Mejía, M. Explaining residents' attitudes to tourism: Is a universal model possible? Ann. Tour. Res. 2011, 38, 460-480. [CrossRef]

18. Lepp, A. Residents' attitudes towards tourism in Bigodi village, Uganda. Tour. Manag. 2007, 28, 876-885. [CrossRef]

19. Akis, S.; Peristianis, N.; Warner, J. Residents' attitude to tourism development: The case of Cyprus. Tour. Manag. 1996, 17, 481-494. [CrossRef]

20. Tosun, C. Host perception of impacts: A comparative tourism study. Ann. Tour. Res. 2002, 29, $231-253$. [CrossRef]

21. Butler, R.W. The concept of a tourist area cycle of evolution: Implications for management of resources. Can. Geogr. 1980, 24, 5-12. [CrossRef]

22. Dogan, H.Z. Forms of adjustment-Sociocultural impacts of tourism. Ann. Tour. Res. 1989, 16, $216-236$. [CrossRef]

23. Mason, P.; Cheyne, J. Residents' attitudes to proposed tourism development. Ann. Tour. Res. 2000, 27, 391-411. [CrossRef]

24. Doxey, G.V. A causation theory of visitor-resident irritants: Methodology and research inferences. In Travel and Tourism Research Associations Sixth Annual Conference Proceedings; Travel Research Association Conference: San Diego, CA, USA, 1975; pp. 195-198.

25. Mason, P. Tourism Impacts, Planning and Management, 2nd ed.; Elsevier/Butterworth Heinemann: Oxford, UK, 2008; Available online: http:/ / books.google.at/books?id=ODfLps-SPssC (accessed on 1 March 2018). 
26. Brida, J.G.; Osti, L.; Faccioli, M. Residents' perception and attitudes towards tourism impacts: A case study of the small rural community of Folgaria (Trentino-Italy). Benchmarking Int. J. 2011, 18, 359-385. [CrossRef]

27. Gursoy, D.; Jurowski, C.; Uysal, M. Resident attitudes: A structural modeling approach. Ann. Tour. Res. 2002, 29, 79-105. [CrossRef]

28. Balaguer, J.; Cantavella-Jorda, M. Tourism as a long-run economic growth factor: The Spanish case. Appl. Econ. 2002, 34, 877-884. [CrossRef]

29. Liu, J.C.; Var, T. Resident attitudes toward tourism impacts in Hawaii. Ann. Tour. Res. 1986, 13, $193-214$. [CrossRef]

30. Uysal, M.; Woo, E.; Singal, M. The Tourist Area Life Cycle (TALC) and its effect on the Quality-of-Life (QOL) of destination community. In International Handbooks of Quality-of-Life. In Handbook of Tourism and Quality-of-Life Research; Uysal, M., Perdue, R., Sirgy, M.J., Eds.; Springer: London, UK, 2012; pp. $423-443$.

31. Trumbo, C.W.; O'Keefe, G.J. Intention to conserve water. Environmental values planned behavior, and information effects: A comparison of three communities sharing a watershed. Tour. Anal. 2001, 9, 1-13.

32. Dale, G. BTEC Level 3 National Travel and Tourism; Edexcel: Harlow, UK, 2010.

33. Mihalič, T. Tourism and economic development issues. In Tourism Development: Concepts and Issues; Sharpley, R., Telfer, D.J., Eds.; Channel View Publications: Clevedon, UK, 2002; pp. 81-111.

34. Hall, C.M.; Lew, A.A. Understanding and Managing Tourism Impacts: An Integrated Approach; Routledge: New York, NY, USA, 2009.

35. Brunt, P.; Courtney, P. Host perceptions of sociocultural impacts. Ann. Tour. Res. 1999, 26, 493-515. [CrossRef]

36. Liu, J.C.; Sheldon, P.J.; Var, T. Resident perception of the environmental impacts of tourism. Ann. Tour. Res. 1987, 14, 17-37. [CrossRef]

37. Jurowski, C.; Uysal, M.; Williams, D.R. A theoretical analysis of host community resident reactions to tourism. J. Travel Res. 1997, 36, 3-11. [CrossRef]

38. Dyer, P.; Gursoy, D.; Sharma, B.; Carter, J. Structural modeling of resident perceptions of tourism and associated development on the Sunshine Coast, Australia. Tour. Manag. 2007, 28, 409-422. [CrossRef]

39. Ambrož, M. Attitudes of local residents towards the development of tourism in Slovenia: The case of Primorska, Dolenjska, Gorenjska and Ljubljana regions. Anthropol. Noteb. 2008, 14, 63-79.

40. Gursoy, D.; Rutherford, D. Host attitudes toward tourism: An improved structural model. Ann. Tour. Res. 2004, 31, 495-516. [CrossRef]

41. Sirakaya, E.; Teye, V.; Sönmez, S.F. Understanding residents' support for tourism development in the central region of Ghana. J. Travel Res. 2002, 41, 57-67. [CrossRef]

42. Ap, J. Residents' perception on tourism impacts. Ann. Tour. Res. 1992, 19, 665-690. [CrossRef]

43. Johnson, J.D.; Snepenger, D.J.; Akis, S. Residents' perceptions of tourism development. Ann. Tour. Res. 1994, 21, 629-642. [CrossRef]

44. Pizam, A.; Pokela, J. The perceived impacts of casino gambling on a community. Ann. Tour. Res. 1985, 12, 147-165. [CrossRef]

45. Kim, K.; Uysal, M.; Sirgy, M.J. How does tourism in a community impact the quality of life of community residents? Tour. Manag. 2013, 36, 527-540. [CrossRef]

46. Gunn, C.A.; Var, T. Tourism Planning: Basics, Concepts, Cases, 4th ed.; Routledge: New York, NY, USA, 2002.

47. World Tourism Organization (UNWTO). International Recommendations for Tourism Statistics. 2008. Available online: http://unstats.un.org/unsd/publication/Seriesm/SeriesM_83rev1e.pdf (accessed on 24 February 2018).

48. Gursoy, D.; Kendall, K. Hosting mega events: Modeling locals' support. Ann. Tour. Res. 2006, 33, $603-623$. [CrossRef]

49. Ko, D.-W.; Stewart, W.P. A structural equation model of residents' attitudes for tourism development. Tour. Manag. 2002, 23, 521-530. [CrossRef]

50. Zamani-Farahani, H.; Musa, G. Residents' attitudes and perception towards tourism development: A case study of Masooleh, Iran. Tour. Manag. 2008, 29, 1233-1236. [CrossRef]

51. Stylidis, D.; Biran, A.; Sit, J.; Szivas, E.M. Residents' support for tourism development: The role of residents' place image and perceived tourism impacts. Tour. Manag. 2014, 45, 260-274. [CrossRef]

52. Ajzen, I. From intentions to actions: A theory of planned behavior. In Action Control: From Cognition to Behavior; Kuhl, J., Beckmann, J., Eds.; Springer: Heidelberg, Germany, 1985; pp. 11-39. 
53. Sharma, B.; Dyer, P. Residents' involvement in tourism and their perceptions of tourism impacts. Benchmarking Int. J. 2009, 16, 351-371. [CrossRef]

54. Williams, J.; Lawson, R. Community issues and resident opinions of tourism. Ann. Tour. Res. 2001, 28, 269-290. [CrossRef]

55. Gursoy, D.; Chi, C.G.; Dyer, P. An examination of locals' attitude. Ann. Tour. Res. 2009, 36, 723-726. [CrossRef]

56. Nunkoo, R.; Smith, S.L.; Ramkissoon, H. Residents' attitudes to tourism: A longitudinal study of 140 articles from 1984 to 2010. J. Sustain. Tour. 2013, 21, 5-25. [CrossRef]

57. Wang, S.; Xu, H. Influence of place-based senses of distinctiveness, continuity, self-esteem and self-efficacy on residents' attitudes toward tourism. Tour. Manag. 2015, 47, 241-250. [CrossRef]

58. Harril, R. Residents' attitudes toward tourism development: A literature review with implications for tourism planning. J. Plan. Lit. 2004, 18, 251-266. [CrossRef]

59. Teye, V.; Sönmez, S.F.; Sirakaya, E. Residents' attitudes toward tourism development. Ann. Tour. Res. 2002, 29, 668-688. [CrossRef]

60. Getz, D. Tourism planning and destination life cycle. Ann. Tour. Res. 1992, 19, 752-770. [CrossRef]

61. Kwon, J.; Vogt, C.A. Identifying the role of cognitive, affective, and behavioral components in understanding residents' attitudes toward place arketing. J. Travel Res. 2010, 49, 423-435. [CrossRef]

62. Andriotis, K.; Vaughan, D.R. Urban residents' attitudes towards tourism development: The case of Crete. J. Travel Res. 2003, 42, 172-185. [CrossRef]

63. Boley, B.B.; McGehee, N.G.; Perdue, R.R.; Long, P. Empowerment and resident attitudes toward tourism: Strengthening the theoretical foundation through a Weberian lens. Ann. Tour. Res. 2014, 49, 33-50. [CrossRef]

64. Boley, B.B.; McGehee, N.G. Measuring empowerment: Developing and validating the Resident Empowerment through Tourism Scale (RETS). Tour. Manag. 2014, 45, 85-94. [CrossRef]

65. Ghanian, M.; Ghoochanie, O.; Crotts, J. An application of European Performance Satisfaction Index towards rural tourism: The case of western Iran. Tour. Manag. 2014, 11, 77-82. [CrossRef]

66. Mithas, S.; Krishnan, M.S.; Fornell, C. Why do customer relationship management applications affect customer satisfaction? J. Mark. 2005, 69, 201-209. [CrossRef]

67. Lankford, S.V. A comment concerning "developing and testing a tourism impact scale". J. Travel Res. 2001, 39, 315-316. [CrossRef]

68. Lankford, S.V.; Howard, D.R. Developing a tourism impact attitude scale. Ann. Tour. Res. 1994, 21, 121-139. [CrossRef]

69. Madden, T.J.; Ellen, P.S.; Ajzen, I. A comparison of the theory of planned behavior and the theory of reasoned action. Pers. Soc. Psychol. Bull. 1992, 18, 3-9. [CrossRef]

70. Sánchez-Cañizares, S.M.; Núñez Tabales, J.M.; Fuentes García, F.J. Local residents' attitudes towards the impact of tourism development in Cape Verde. Tour. Manag. Stud. 2014, 10, 87-96.

71. Abler, R. Human Geography in a Shrinking World, North Scituate, Mass; Duxbury Press: New York, NY, USA, 1975.

72. Bjorklund, E.; Philbrick, A. Spatial configurations of mental recreation and park processes. In Building Regions for the Future; Belanger, M., Janelle, D., Eds.; Department of Geography, Lowal University: Quebec, QC, Canada, 1975; pp. 57-75.

73. Nunkoo, R.; Ramkissoon, H. Gendered theory of planned behaviour and residents' support for tourism. Curr. Issues Tour. 2010, 13, 525-540. [CrossRef]

74. Zenker, S.; Braun, E. Questioning a "one size fits all" city brand: Developing a branded house strategy for place brand management. J. Place Manag. Dev. 2017, 10, 270-287. [CrossRef]

75. Zenker, S.; Braun, E.; Petersen, S. Branding the destination versus the place: The effects of brand complexity and identification for residents and visitors. Tour. Manag. 2017, 58, 15-27. [CrossRef]

76. Kollmuss, A.; Agyeman, J. Mind the Gap: Why do people act environmentally and what are the barriers to pro-environmental behavior? Environ. Educ. Res. 2002, 8, 239-260. [CrossRef]

77. Chen, M.F.; Tung, P.J. Developing an Extended Theory of Planned Behavior Model to Predict Consumers' Intention to Visit Green Hotels. Int. J. Hosp. Manag. 2014, 36, 221-230. [CrossRef]

78. Halpenny, E.A. Pro-environmental Behaviours and Park Visitors: The Effect of Place Attachment. J. Environ. Psychol. 2010, 30, 409-421. [CrossRef]

79. King, B.; Pizam, A.; Milman, A. Social impacts of tourism: Host perceptions. Ann. Tour. Res. 1993, 20, 650-665. [CrossRef] 
80. Haralambopoulos, N.; Pizam, A. Perceived impacts of tourism: The case of Samos. Ann. Tour. Res. 1996, 23, 503-526. [CrossRef]

81. Pérez, E.A.; Nadal, J.R. Host community perceptions: A cluster analysis. Ann. Tour. Res. 2005, 43, 925-941. [CrossRef]

82. Wang, Y.; Pfister, R.E. Residents' attitudes toward tourism and perceived personal benefits in a rural community. J. Travel Res. 2008, 47, 84-93. [CrossRef]

83. Brougham, J.E.; Butler, R.W. A segmentation analysis of resident attitudes to the social impact of tourism. Ann. Tour. Res. 1981, 8, 569-590. [CrossRef]

84. Smith, M.D.; Krannich, R.S. Tourism dependence and resident attitudes. Ann. Tour. Res. 1998, 25, 783-802. [CrossRef]

85. Upchurch, R.S.; Teivane, U. Resident perceptions of tourism development in Riga, Latvia. Tour. Manag. 2000, 21, 499-507. [CrossRef]

86. Belisle, F.J.; Hoy, D.R. The perceived impact of tourism by residents: A case study in Santa Marta, Colombia. Ann. Tour. Res. 1980, 7, 83-101. [CrossRef]

87. Weaver, D.B.; Lawton, L.J. Resident perceptions of a contentious tourism event. Tour. Manag. 2013, 37, 165-175. [CrossRef]

88. Brasier, K.J.; Filteau, M.R.; McLaughlin, D.K.; Jaquet, J.; Stedman, R.C.; Kelsey, T.W.; Goetz, S.J. Residents' perceptions of community and environmental impacts from development of natural gas in the Marcellus Shale: A comparison of Pennsylvania and the New York cases. J. Rural Soc. Sci. 2011, 26, 52-61.

89. Kaltenborn, B.P. Effects of sense of place on responses to environmental impacts. Appl. Geogr. 1998, 18, 169-189. [CrossRef]

90. Projekt Spielberg. Das Projekt Spielberg. Available online: www.projekt-spielberg.com (accessed on 22 April 2018).

91. Urlaubsregion Murtal. Tourismus Fact Sheet Regionsprofil. Verwaltung Steiermark. Available online: http:/ / www. verwaltung.steiermark.at/cms/dokumente/ (accessed on 22 April 2018).

92. Statistik Steiermark. Fremdenverkehrsstatistik-Direktabfrage. Available online: http://www.statistik. steiermark.at/cms/beitrag/12004223/103035336/ (accessed on 1 December 2016).

93. Creswell, J.W. Research Design: Qualitative, Quantitative, and Mixed Methods Approaches, 4th ed.; Sage Publications: Thousand Oaks, CA, USA, 2014.

94. Muijs, D. Doing Quantitative Research in Education with SPSS, 2nd ed.; Sage Publications: London, UK, 2010.

95. Veal, A.J. Research Methods for Leisure and Tourism: A Practical Guide, 4th ed.; Prentice Hall: Harlow, UK, 2011.

96. Bryman, A.; Bell, E. Business Research Methods, 3rd ed.; Oxford University Press: Cambridge, UK; New York, NY, USA, 2011.

97. Raithel, J. Quantitative Forschung: Ein Praxiskurs, 2nd ed.; Springer: Wiesbaden, Germany, 2008.

98. Riva, G.; Teruzzi, T.; Anolli, L. The Use of the Internet in psychological research: Comparison of online and offline questionnaires. Cuberpsychol. Behav. 2003, 6, 73-80. [CrossRef] [PubMed]

99. Weijters, B.; Cabooter, E.; Schillewaert, N. The effect of rating scale format on response styles: The number of response categories and response category labels. Int. J. Res. Mark. 2010, 27, 236-247. [CrossRef]

100. Chomeya, R. Quality of psychology test between Likert Scale 5 and 6 points. J. Soc. Sci. 2010, 6, $399-403$.

101. Dolnicar, S.; Grun, B. Environmentally friendly behavior-can heterogeneity among individuals and contexts/environments be harvested for improved sustainable management? Environ. Behav. 2009, 41, 693-714. [CrossRef]

102. Dolnicar, S.; Grun, B. Validly measuring destination image in survey studies. J. Travel Res. 2013, 52, 3-14. [CrossRef]

103. Byrd, E.T.; Bosley, H.E.; Dronberger, M.G. Comparisons of stakeholder perceptions of tourism impacts in rural eastern North Carolina. Tour. Manag. 2009, 30, 693-703. [CrossRef]

104. Perdue, R.R.; Long, P.T.; Allen, L. Resident support for tourism development. Ann. Tour. Res. 1990, 17, 586-599. [CrossRef]

105. McGehee, N.G.; Andereck, K.L.; Vogt, A.C. An Examination of Factors Influencing Resident Attitudes Toward Tourism in Twelve Arizona Communities. 2002. Available online: http:/ / www.ttra.com (accessed on 1 March 2018).

106. Haley, A.J.; Snaith, T.; Miller, G. The social impacts of tourism: A case study of Bath, UK. Ann. Tour. Res. 2005, 32, 647-668. [CrossRef]

107. Fredline, E.; Faulkner, B. Host community reactions. Ann. Tour. Res. 2000, 27, 763-784. [CrossRef] 
108. Backhaus, K. Multivariate Analysemethoden: Eine Anwendungsorientierte Einführung; Springer: Berlin, Germany, 2011.

109. Kline, P. The Handbook of Psychological Testing, 2nd ed.; Routledge: London, UK; New York, NY, USA, 2000.

110. Hornburg, C.; Giering, A. Konzeptualisierung und Operationalisierung komplexer Konstrukte. Ein Leitfaden für die Marketingforschung. Mark. ZFP 1996, 18, 5-24.

111. Fox, J. Applied Regression Analysis, Linear Models, and Related Models; Sage Publications: Thousand Oaks, CA, USA, 1997.

112. Dancey, C.P.; Reidy, J. Statistics without Maths for Psychology, 5th ed.; Prentice Hall: Harlow, UK; New York, NY, USA, 2011.

113. Page, S. Urban Tourism; Routledge: London, UK; New York, NY, USA, 1995.

114. Sinclair-Maragh, G.; Gursoy, D.; Vieregge, M. Residents' perceptions toward tourism development: A factor-cluster approach. J. Dest. Mark. Manag. 2015, 4, 36-45.

115. Brida, J.G.; Riano, E.; Aguirre, S.Z. Residents' attitudes and perceptions towards cruise tourism development: A case study of Cartagena de Indias (Colombia). Tour. Hosp. Res. 2011, 11, 181-196. [CrossRef]

116. McCool, S.F.; Martin, S.R. Community attachment and attitudes toward tourism development. J. Travel Res. 1994, 32, 29-34. [CrossRef]

117. Vargas-Sánchez, A.; Oom do Valle, P.; da Costa Mendes, J.; Silva, J.A. Residents' attitude and level of destination development: An international comparison. Tour. Manag. 2015, 48, 199-210. [CrossRef]

(C) 2018 by the authors. Licensee MDPI, Basel, Switzerland. This article is an open access article distributed under the terms and conditions of the Creative Commons Attribution (CC BY) license (http://creativecommons.org/licenses/by/4.0/). 